\title{
A constrained African craton source for the Cenozoic Numidian Flysch: Implications for the palaeogeography of the western Mediterranean basin
}

\author{
M.F.H. Thomas *, S. Bodin ${ }^{1}$, J. Redfern, D.H.B. Irving \\ North Africa Research Group. School of Earth, Atmospheric and Environmental Sciences. The University of Manchester, Williamson building, Oxford Road, Manchester, \\ M13 9PL, United Kingdom
}

\section{A R T I C L E I N F O}

\section{Article history:}

Received 1 June 2009

Accepted 22 March 2010

Available online 1 April 2010

\section{Keywords:}

Numidian Flysch

Cenozoic

provenance

zircon

turbidite

palaeocurrent

\begin{abstract}
A B S T R A C T
The provenance of the Numidian Flysch in the western Mediterranean remains a controversial subject which hinders understanding of this regionally widespread depositional system. The Numidian Flysch is a deep marine formation dated as Oligocene to Miocene which outcrops throughout the Maghreb and into Italy. Evidence that is widely used for provenance analysis has not previously been reviewed within the context of the Maghrebian Flysch Basin as a whole. The structural location within the Alpine belt indicates deposition proximal to the African margin, while the uniformity of the Numidian Flysch petrofacies suggests a single cratonic source, in stark contrast to heterolithic and immature flysch formations from the north of the basin. Detrital zircon ages constrain a source region with Pan-African and Eburnian age rocks, unaffected by either Hercynian or Alpine tectonic events, which precludes the European basement blocks to the north of the basin. Palaeocurrent trends which suggest a northern source are unreliable given foreland basin analogues and observed structural complications. An African craton source remains the only viable option once these data are reviewed in their entirety, and the Numidian Flysch therefore represents a major Cenozoic drainage system on the North African margin. Deposition is concurrent with regional Atlas uplift phases, and coincidental with globally cooling climates and high sea levels. The Numidian Flysch is therefore interpreted to represent a highstand passive margin deposit, with timing of deposition controlled primarily by hinterland uplift and climatic fluctuations.
\end{abstract}

(c) 2010 Elsevier B.V. All rights reserved.

\section{Contents}

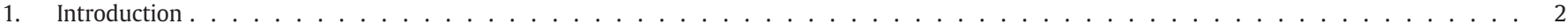

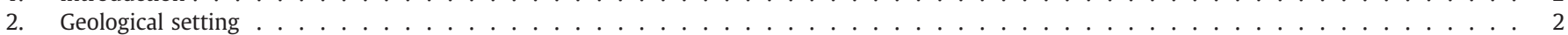

3. Evidence for the Numidian Flysch provenance . . . . . . . . . . . . . . . . . . . . . . . . . . . . . . . . 4

3.1. Structural position within Alpine nappes . . . . . . . . . . . . . . . . . . . . . . . . . . 5

3.1.1. The Sicilide basin of Sicily and southern Italy . . . . . . . . . . . . . . . . . . . . . . 5

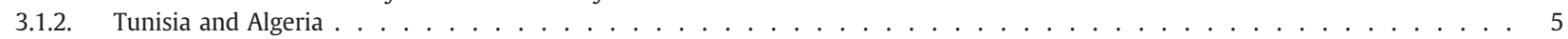

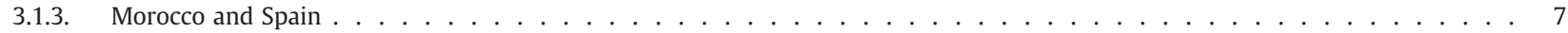

3.2. Petrology of Numidian Flysch sandstones and mudstones . . . . . . . . . . . . . . . . . . . . . . . 7

3.3. Palaeoflow orientations of density flow deposits. . . . . . . . . . . . . . . . . . . . . . . . . . . . . . . . . 8

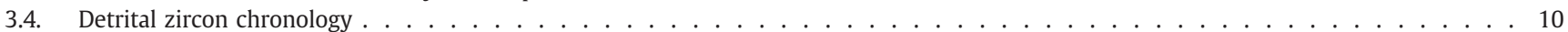

4. Drawing conclusions about Numidian Flysch provenance . . . . . . . . . . . . . . . . . . . . . . . 11

4.1. Is the Numidian Flysch sourced from a single region? . . . . . . . . . . . . . . . . . . . . . . . . . . . . . 11

4.2. A northern or southern source $\ldots \ldots \ldots \ldots \ldots \ldots$

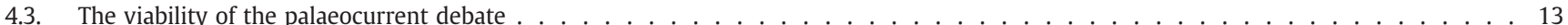

5. Implications of a constrained African source . . . . . . . . . . . . . . . . . . . . . . . . . . . 13

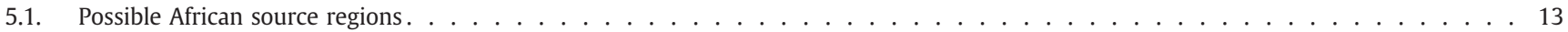

5.2. Location and timing of Numidian Flysch sediment input . . . . . . . . . . . . . . . . . . . . . . . . . . . . . . . . . . . . . . . . . . .

\footnotetext{
* Corresponding author. Tel.: +44 161275 7679; fax: +44 1613069361.

E-mail addresses: myron.thomas@manchester.ac.uk (M.F.H. Thomas), stephane.bodin@ruhr-uni-bochum.de (S. Bodin), jonathan.redfern@manchester.ac.uk (J. Redfern), duncan.irving@manchester.ac.uk (D.H.B. Irving).

${ }^{1}$ Present address: Institute for Geology, Mineralogy and Geophysics, Ruhr-University Bochum, Universitätsstrasse 150, D-44801 Bochum, Germany.
} 
5.2.1. Timing of deposition versus basin tectonics . . . . . . . . . . . . . . . . . . . . . 14

5.2.2. The location and style of sediment input . . . . . . . . . . . . . . . . . . . . . . . . . . . . . . . 14

5.3. Controls upon Numidian Flysch sedimentation. . . . . . . . . . . . . . . . . . . . . . . . . . 15

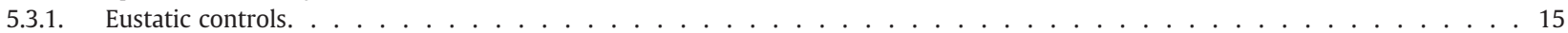

5.3.2. Tectonic controls . . . . . . . . . . . . . . . . . . . . . . . . . . 17

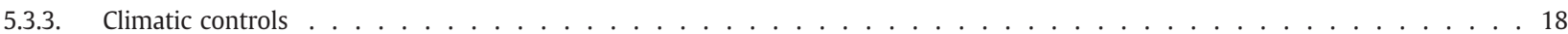

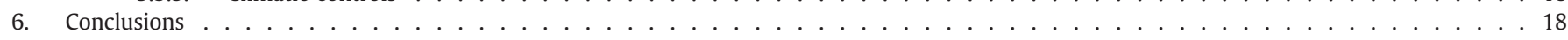

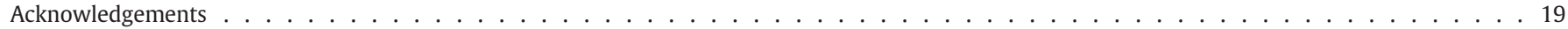

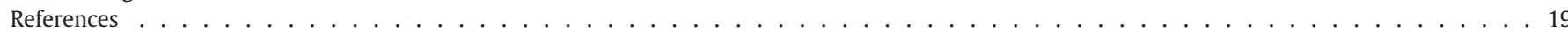

\section{Introduction}

The Cenozoic Numidian Flysch is a foreland basin deposit representing the most widespread tectono-stratigraphic unit in the western Mediterranean (Wezel, 1970a; Dejong, 1975) (Fig. 1). Numidian Flysch sediments were fed into the east-west oriented foreland basin (Mahgrebian Flysch Basin (MFB)) which resided in the western palaeo-Tethys realm between a growing accretionary prism to the north and the passive African margin to the south (Elter et al., 2003; Guerrera et al., 2005). Facies include hemipelagic mudstones and a variety of density flow deposits both unconfined and confined within channel bodies (Vila et al., 1995; Johansson et al., 1998) (Fig. 2). Depositional environment is assigned to both the slope and basin floor environments within a deep marine setting (e.g. Wezel, 1969; Johansson et al., 1998; Riahi et al., 2007). Displaying a seemingly continuous ultramature quartzarenite petrofacies throughout the western Mediterranean, the Numidian Flysch has been a formation of great controversy regarding its provenance since the 1950s (Gottis, 1953; Wezel, 1970a; Caire and Duée, 1971). Attempts to reconcile this fundamental problem have been hampered by its homogeneous nature and the complexity of its allocthonous emplacement. Its vast regional extent $(>2000 \mathrm{~km})$ has also lead some authors to promote it as a facies rather than a single formation (Magné and Raymond, 1972; Giunta, 1985; Moretti et al., 1991). Its source region has ultimately been described as being northern, from European terrains and the foreland basin orogenic wedge; southern from the African craton; or a mixture of both. Evidence has focused upon its structural position relative to other units within the basin, petrology of the clastic fraction, ages of detrital zircons, and palaeocurrent orientations. Progress has stagnated in recent years with heated debate over palaeocurrent orientations giving no obvious conclusion (see Johansson et al., 1998; Parize et al., 1999; Stow et al., 1999). More recently, work has spread to provenance analysis of mudstones rather than the clastic fraction which has failed to resolve the debate so far (Barbera et al., 2009). The lack of a definitive source area has hampered understanding of the Numidian Flysch system as a whole, and little evidence exists concerning either basin architecture or controls upon deposition. The duration and large regional extent of Numidian Flysch deposition potentially offers an insight into the palaeogeography and drainage in the entire western Mediterranean once these problems are addressed. Here we present the first integrated critical review of the published evidence on provenance, together with additional field and petrological data, in order to constrain the source of the Numidian Flysch and place it within a palaeogeographic framework of the western Mediterranean during the Cenozoic.

\section{Geological setting}

The Mahgrebian Flysch Basin (MFB) represents a major MesoCenozoic domain of the Alpine orogenic belt (Guerrera et al., 2005) which today marks the northern extent of the African margin from Morocco to southern Italy (Wezel, 1970a) (Fig. 1). The basin, a remnant of the neo-Tethys ocean, lay to the north of the African margin and trended approximately east-west, linking the Atlantic and eastern Mediterranean domains (Piqué et al., 2002; Guerrera et al., 2005) (Fig. 3). The original oceanic basin was initiated through the northwards separation of Eurasia from Gondwana during the Jurassic breakup of Pangea (Golonka, 2004). An east-west trending group of continental microplates, variously termed the Meso-Mediterranean Terrain (MMT) (Guerrera et al., 1993; de Capoa et al., 2004; Zaghloul et al., 2007) or AlKaPeCa domain ( $\mathrm{Al}=$ Alboran block, $\mathrm{Ka}=$ Kabylie

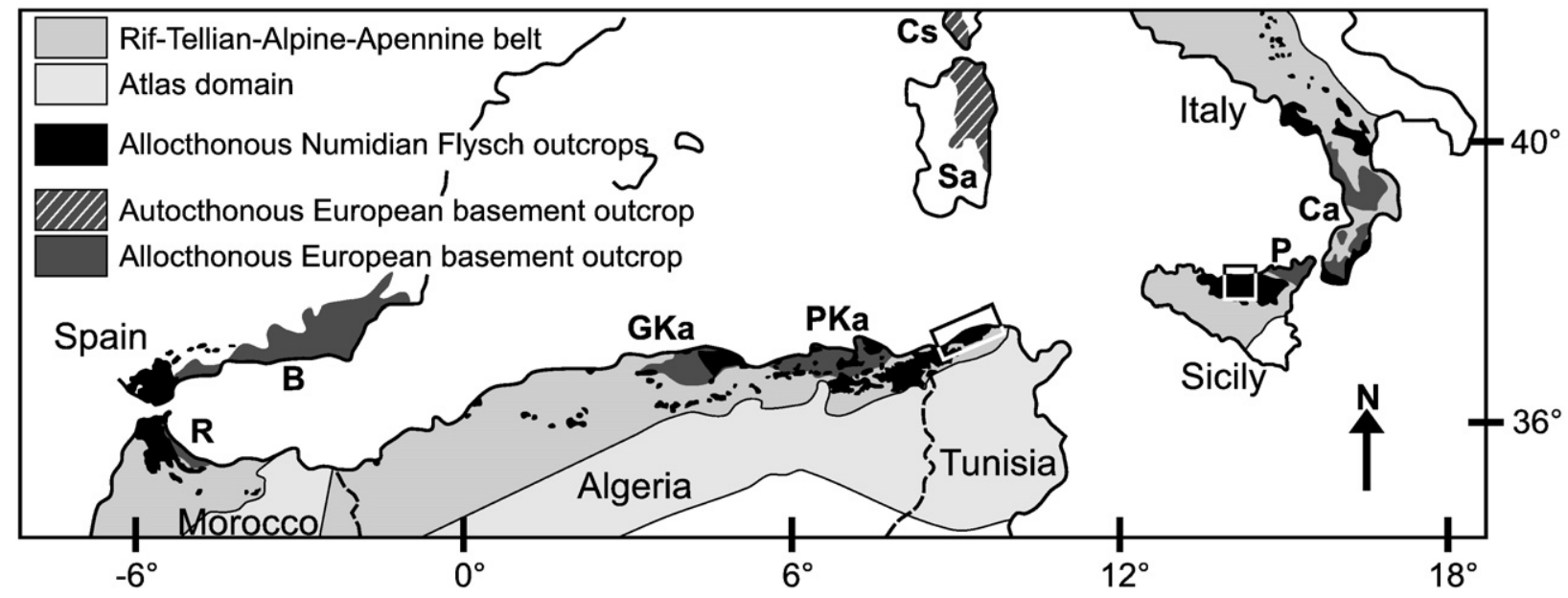

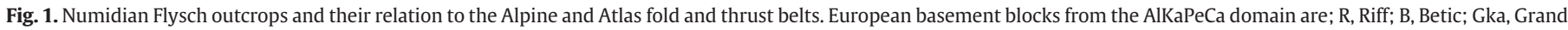

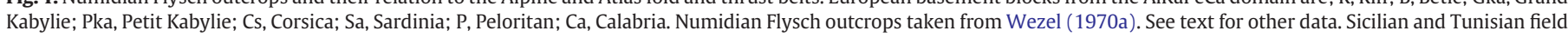
areas used for this study are boxed. 

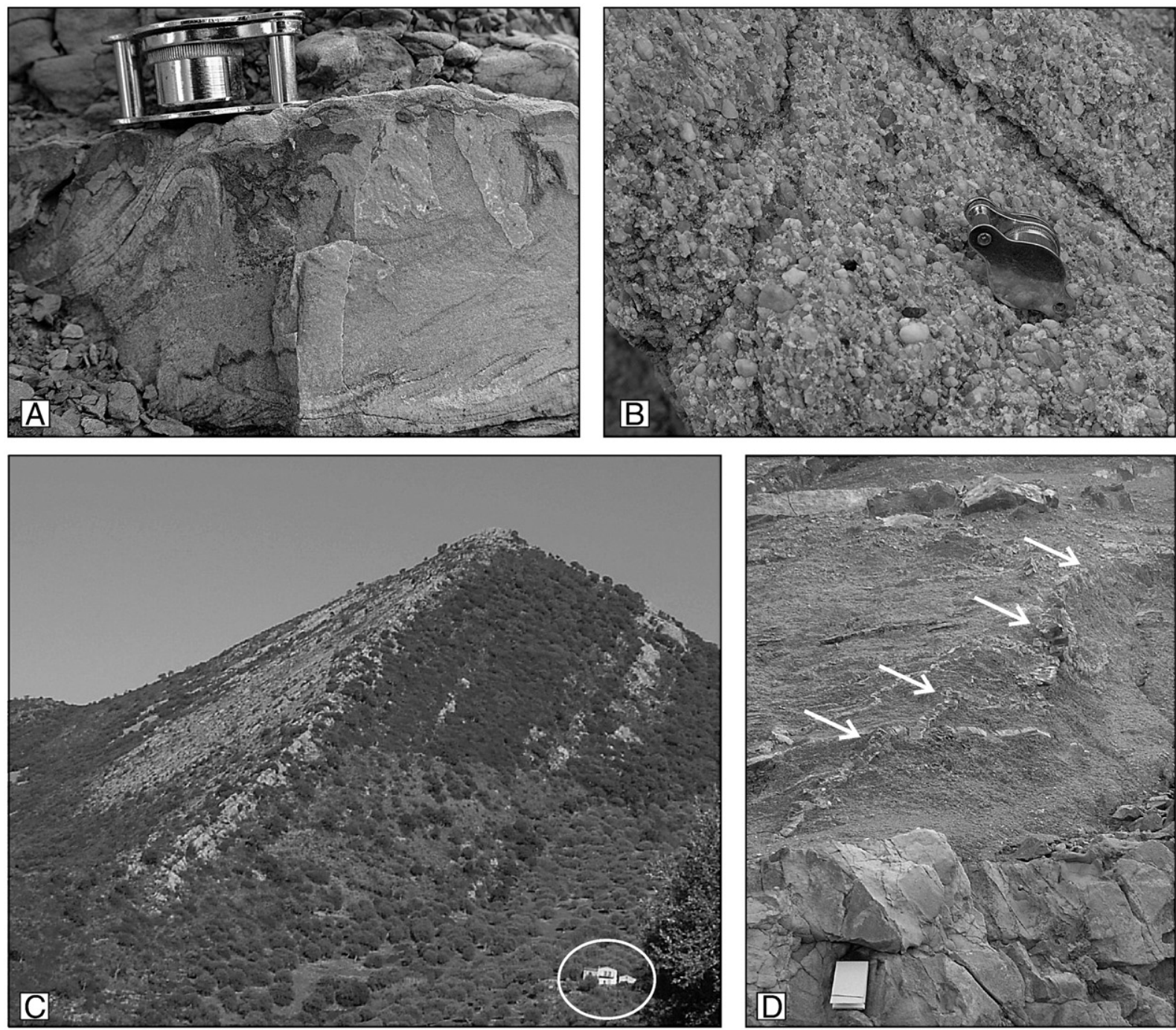

North

South

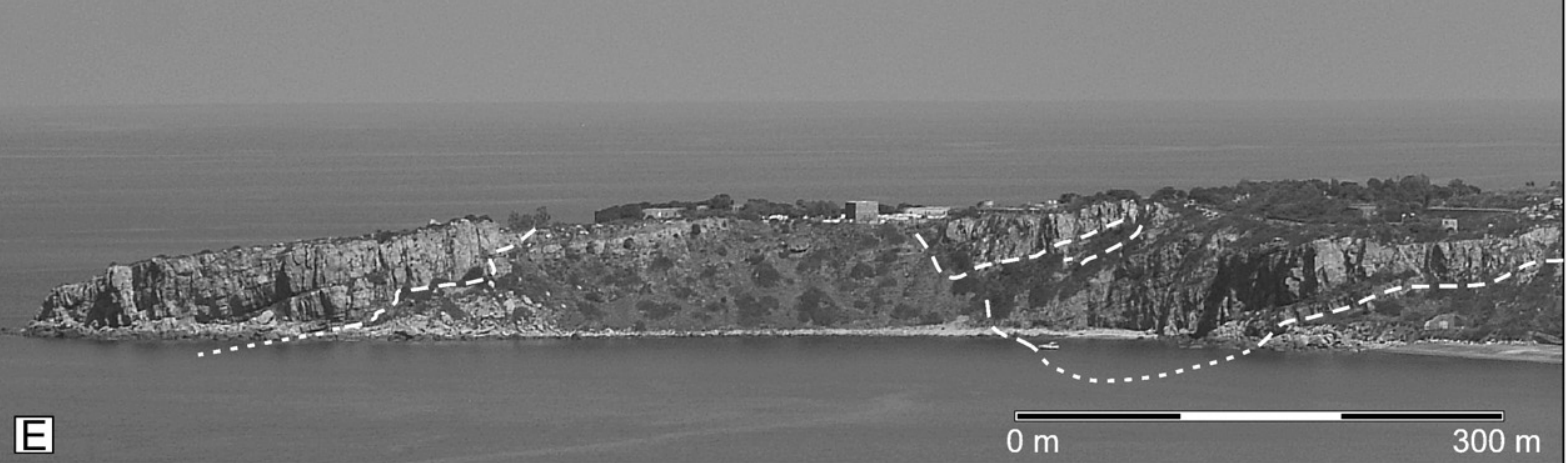

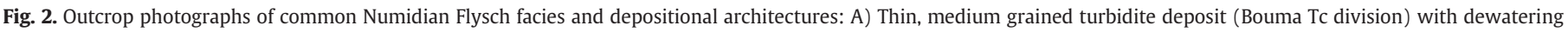

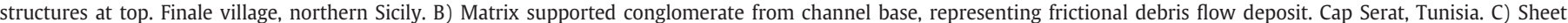

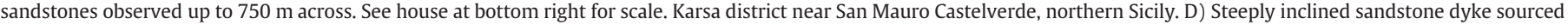
from unstructured medium grained sandstone bed at base. Tabarka. Tunisia. E) Coastal exposure of large scale incisional channel complexes. Finale village, northern Sicily.

block, $\mathrm{Pe}=$ Peloritan block, $\mathrm{Ca}=$ Calabrian block (sensu Bouillin et al., 1986) formed the northern border of the Mahgrebian basin (Figs. 1, 3), also rifted from the Eurasian plate in the Jurassic (Cohen, 1980; Guerrera et al., 1993). Basement lithologies of the AlKaPeCa domain include phyllites, amphibolite facies rocks, mica-shists, granites and volcanics (Trombetta et al., 2004; Festa et al., 2006; Hammor et al., 2006). African oceanic crust, basement to the MFB, was subducted to the north beneath the AlKaPeCa domain from the Eocene (Lentini et al., 2002; Golonka, 2004) such that the MFB became a true foreland basin. The AlKaPeCa domain migrated southwards towards the African margin from the upper Oligocene (Puglisi, 2008), coincident with counter-clockwise rifting of Corsica and Sardinia from Europe, and the opening to their north of the Algerian basin (Mauffret et al., 2004). The rotation and southwards migration of the Sardinia/Corsica block, coupled with subduction-related slab roll-back were the main geodynamic controls upon the eastern sector of the MFB from the late 


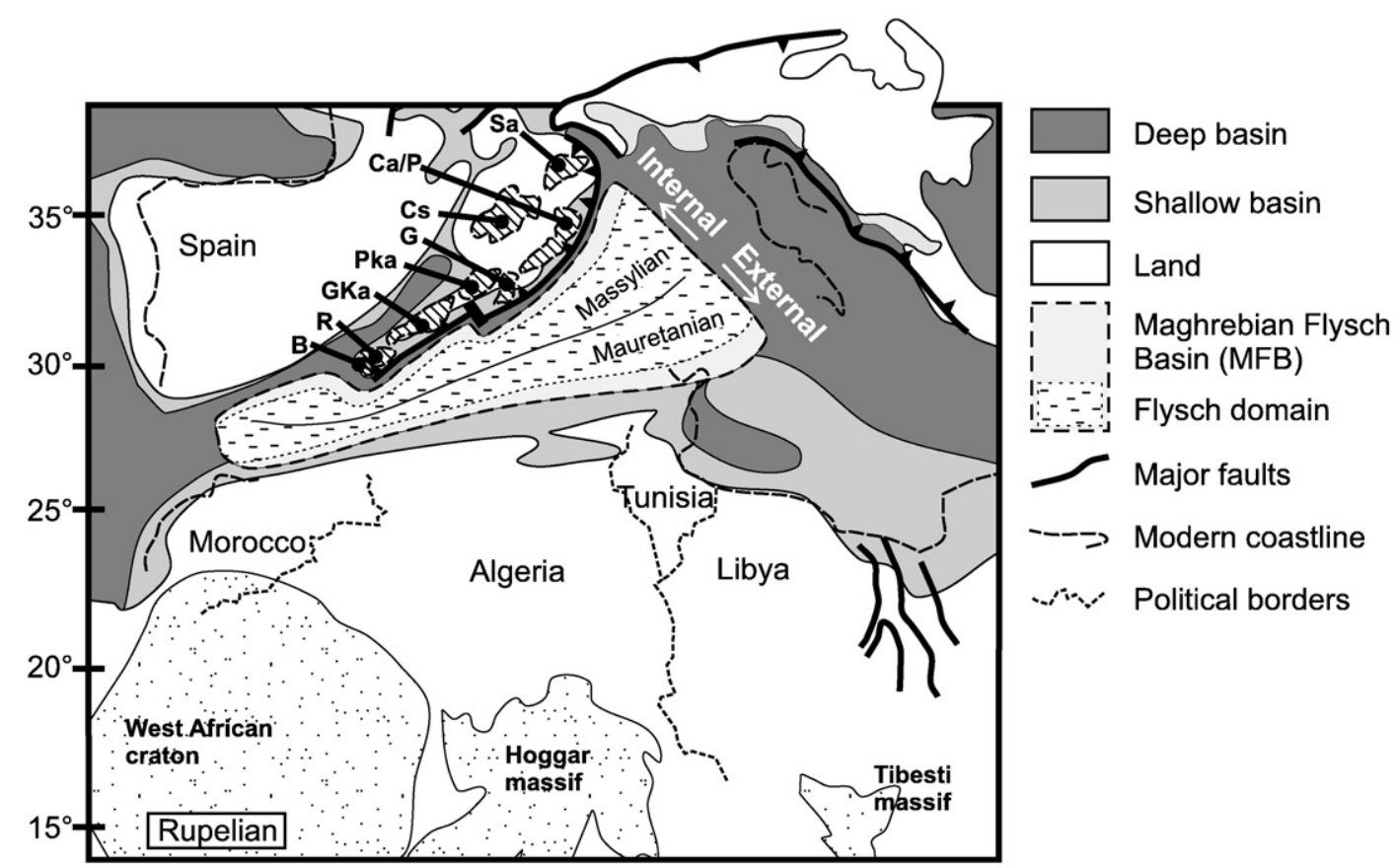

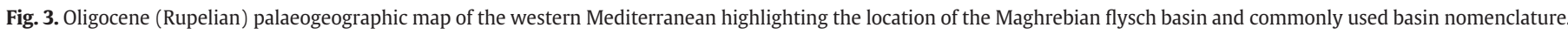

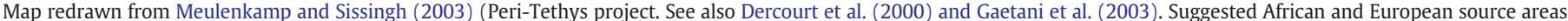

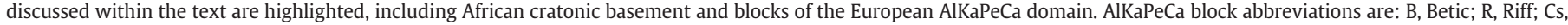
Corsica; Sa, Sardinia; Ca/P, Calabria and Peloritan; G, Galite block; Pka, Petit Kabylie; Gka, Grand Kabylie.

Eocene (Cohen, 1980; Carminati et al., 1998; Mauffret et al., 2004). Portions of the AlKaPeCa domain also formed basement to a magmatic arc during migration, shedding volcaniclastic sediment to the MFB and possibly north to the Algerian basin (de Capoa et al., 2002; Mauffret et al., 2004).

With migration, the continental AlKaPeCa domain formed the basement to a growing south-verging orogenic wedge, preceded to its south and east by thin-skinned thrust deformation (Knott, 1987; Putignano and Schiattarella, 2008). Fig. 3 highlights the geographic terminology used within this review. Internal units from the north of the basin and proximal to the young accretionary wedge, were incorporated into thrust nappes relatively early within the Aquitanian (de Capoa et al., 2004; Guerrera et al., 2005; de Capoa et al., 2007). These units are found today structurally or conformably overlying the AlKaPeCa basement (de Capoa et al., 2002; Guerrera et al., 2005). External units conformably or structurally overlie both the African carbonate platform and Tellian units of the southern passive margin, and became structured in the latest Burdigalian (de Capoa et al., 2004). Deep marine 'flysch' units from the foredeep area of the basin define a flysch domain mid way between these internal and external areas. The flysch domain is in turn split into a northern Mauretanian subdomain which is characterised by a metamorphic/volcaniclastic rich petrofacies, and a southern Massylian subdomain characterised by a quarzose petrofacies (Gelard, 1969; Bouillin and Glacon, 1973; de Capoa et al., 2004). So-called mixed successions which have characteristics of both Mauretanian and Massylian subdomains are described throughout the entire chain, and have been interpreted to be the result of mixing of the two petrofacies in the foredeep axis (Carmisciano et al., 1987; Fornelli, 1998).

Numidian Flysch deposits are unanimously regarded as having ages that span the Oligocene to early Miocene compressional foreland basin stage (Lahondére et al., 1979; Leblanc and Feinberg, 1982; Didon et al., 1984; Faugères et al., 1992; Torricelli and Biffi, 2001). Numidian Flysch deposits in Morocco, Algeria, Tunisia, and Italy are relatively well dated, however Sicilian deposits have not been well constrained. Unpublished biostratigraphic dating undertaken for this study in Sicily using planktonic and benthic foraminifera as well as radiolaria, have constrained the Sicilian deposits to an Aquitanian Burdigalian age.

On the African margin, the large Fortuna Delta system in Tunisia was contemporaneous with the Numidian Flysch, and fed sediment east and south towards the Pelagian basin. The delta has been commonly cited as a potential Numidian Flysch input point in northern Tunisia (Vanhouten, 1980; Yaich et al., 2000). Closure of the MFB, resulting from southwards migration of the AlKaPeCa domain, occurred in the early to mid-Miocene, and resulted in stacking of MFB deposits upon the African passive margin (Carr and Miller, 1979; de Capoa et al., 2004).

\section{Evidence for the Numidian Flysch provenance}

Since the earliest major works on the Numidian Flysch by Wezel (1969) and Wezel (1970b), the provenance of the numidian detrital supply has been contested. Studies concerned primarily with regional tectonics and stratigraphy have generally preferred the African craton as the most likely source region, and this has been supported by petrological studies which relate the rounded ultramature quartz pebbles to a cratonic source. There have also been some attempts to use zircon age dating to constrain the source region which have however met with little reaction from a majority of subsequent publications. Sedimentologists have tended to suggest a northern source however, prompted primarily by the orientation of sole marks on the base of density flow deposits (e.g. Parize et al., 1986; Yaich, 1992a). Foreland basin examples such as the Apennines and Alps also suggests that in foreland basin settings, a majority of flysch sediment is commonly sourced from the tectonically active accretionary prism, which in the MFB would be located at its northern margin. This division of ideas related to provenance, remains prevalent within the literature, with the two main protagonist groups maintaining their positions.

Possible northern source regions include continental basement from mainland Europe, or terrains rifted from it, such as the AlKaPeCa microplates, Corsica, and Sardinia (Fig. 3). Specific source regions are rarely cited, although Sardinia (Caire and Duée, 1971) and the Kabylie 
blocks (Magné and Raymond, 1972; Ivaldi, 1977; Lahondére et al., 1979; Vila et al., 1995; Fildes et al., 2010) have been suggested. Supporters of a southern source have variously suggested the Continental Intercalaire (Lancelot et al., 1976; Ivaldi, 1977; Moretti et al., 1991) and Pharusian series (Moretti et al., 1991) of western and central Africa, the Nubian sandstone of the Sirt basin in Libya (Wezel, 1970a; Johansson et al., 1998) and Permo-Triassic and Ordovician continental sandstones of southern Tunisia (Gaudette et al., 1975; Gaudette et al., 1979).

Four key lines of evidence are therefore commonly used: The structural position of Numidian Flysch nappes constrains the depositional location of the Numidian Flysch and its palaeogeography within the basin; petrological studies of the Numidian Flysch have allowed differentiation with flysch deposits of the Mauretanian subdomain, and comparison of its characteristics with those predicted from provenance models; palaeocurrent analysis has been used to determine the direction that density flows travel from source to depositional location, thereby assessing the source orientation; finally, zircon analysis has been used to constrain source rock ages. In general, these lines of evidence are discussed individually within a majority of publications. Here they are presented and reviewed sequentially, before being integrated together.

\subsection{Structural position within Alpine nappes}

The location of the Numidian Flysch within the Alpine thrust belt provides evidence as to its position relative to the AlKaPeCa domain and the North African passive margin. Early nappe emplacement and an internal/structurally high position within the nappe pile constrain units to a pre-allocthonous position proximal to the orogenic wedge and the north of the basin (Boyer and Elliott, 1982; de Capoa et al., 2002). Similarly, late stage nappe emplacement and an external/ structurally low position within the nappe pile constrain units to a pre-allocthonous position to the south of the Mauretanian subdomain and proximal to the North African passive margin. This line of evidence is well established in Morocco, Sicily and Italy where the majority of work has been performed. A summary of the following tectono-stratigraphic relationships is presented in Fig. 4.

\subsubsection{The Sicilide basin of Sicily and southern Italy}

Commonly grouped as the Sicilide basin, the sedimentological and tectonic evolution of both Sicily and southern Italy are very similar. The Numidian Flysch in northern Sicily, exposed in stacked southverging nappes, lies conformably upon Eocene platform carbonates and Oligocene mudstones of the Imerese and Panormide carbonate platforms (Wezel, 1969; Faugères et al., 1992; Johansson et al., 1998). Structurally above and to the north of the Numidian Flysch, units of the Troina Tusa nappes contain Oligocene to early Miocene volcaniclastic arenites (the Tusa Tuffite Fm) (Fig. 4) unconformably overlain by the volcaniclastic Reitano flysch, of either Langhian or Serravellian age, which seals the nappes of the Mauretanian flysch domain (Cassola et al., 1995; de Capoa et al., 2000). The Troina Tusa Flysch (Troina Tusa nappe), a micaceous sandstone with volcaniclastic intervals is contemporaneous with the Numidian Flysch and crops out in northeast and central Sicily within the same succession (Lancelot et al., 1977; Barbera et al., 2009). The northern Numidian Flysch and its immediate substrate were detached in the Langhian and displaced southwards over more external carbonate domains in the early Tortonian (Catalano et al., 1995). In contrast, southern deposits which crop out in central Sicily lie conformably upon Oligocene to Aquitanian deep marine basinal mudstones of the Argille Varicolori Fm (Carbone et al., 1987; de Capoa et al., 2000). The European Peloritani basement massif (AlKaPeCa domain), largely submerged offshore northern Sicily, crops out in the northeastern Peloritani mountains, unconformably overlain by porphyric clast turbidite deposits of the Upper Oligocene-Lower Miocene Stilo-Capo d'Orlando
Formation (Bonardi et al., 1980; Mazzoleni, 1991; Patterson et al., 1995). Continental collision of the Peloritani block with Africa occurred in the Serravellian and was completed by the late Tortonian (de Capoa et al., 2004).

In southern Italy, east verging Numidian Flysch nappes directly overlie Oligocene to early Miocene carbonates and calcarenites of the Apulia margin (Cerchiara Fm) (Iannace et al., 2007). Structurally higher to the west lie nappes of varicoloured clays and the Tufiti di Tusa Fm as recognised in Sicily (Pescatore et al., 1992; Lentini et al., 2002) (Fig. 4). Eastward continental collision of the Calabria block with the African Apulia margin took place in the late Miocene (Cello and Mazzoli, 1998; Iannace et al., 2007).

\subsubsection{Tunisia and Algeria}

Less agreement exists about the structural evolution of the Alpine chain of northern Tunisia and Algeria. The Numidian Flysch crops out in the Alpine belt which strikes roughly parallel to the northern coastline, subsequently turning north at Ras el Koran to become submerged offshore in the Sicily channel (Catalano et al., 1996). South of the Alpine belt, units of the African Tellian domain represent continental and marine sediments, and debate in Tunisia has centred around the relationship of the Numidian Flysch to underlying Tellian units being either allocthonous, parautocthonous, or autocthonous. Recent work confirms them to be allocthonous through the use of biostratigraphy and the relationship of Numidian Flysch deposits to the underlying Tellian deposits (Riahi et al., 2007; Talbi et al., 2008; Boukhalfa et al., 2009) (Fig. 4). Furthermore, biostratigraphic and palynostratigraphic dating of the Numidian Flysch series confirms the vertical superposition of three coeval members (the Zousa, Kroumerie and Babouche members) and their subsequent lateral juxtaposition to the external shallow marine Bejaoua Group (Torricelli and Biffi, 2001; El Euchi et al., 2004; Riahi et al., 2007; Boukhalfa et al., 2009). The Numidian Flysch is therefore stacked above the external Tellian units, which are in turn stacked upon the African foreland (Burollet, 1991; El Euchi et al., 2004; Boukhalfa et al., 2009).

The European basement Galite block (AlKaPeCa domain), a lateral equivalent to the Kabylies of northern Algeria, does not outcrop. It is interpreted, using marine 2D seismic surveys and dredged samples, to lie to the north of the Tunisian coast (Tricart et al., 1994), stacked upon Numidian Flysch nappes (Tricart et al., 1994; El Euchi et al., 1998, 2004) (Fig. 4). Galite island, $50 \mathrm{~km}$ north of the Tunisian mainland also shows a juxtaposition of Numidian Flysch quartz rich sandstones, immature litharenite turbidites of the Galite Flysch and some stratigraphic intervals of mixed successions (Belayouni et al., 2010). Early Miocene arkosic turbidites have also been recovered in dredge samples from the offshore Galite area (Tricart et al., 1994).

The location of the Numidian Flysch in Algeria has fuelled a debate about where the Numidian Flysch basin lay with respect to the internal European Kabylie basement (AlKaPeCa domain). The Numidian Flysch outcrops throughout the width of the Alpine belt, thrust above African Tellian units in the south. In northern Algeria the Numidian Flysch lies above and to the north of the Kabylie blocks on the Algerian coastline (Magné and Raymond, 1972; Moretti et al., 1991). This relationship is contrary to that observed throughout the rest of the basin, and has prompted some authors to view the Numidian Flysch as conformable cover to the European Kabylie blocks rather than a deposit of the Massylian subdomain to the south (Laval, 1974; Coutelle, 1979; Laval, 1992) (Fig. 4). In order to account for recorded Numidian Flysch palaeocurrent orientations and a position conformable with the Kabylie blocks, Laval (1992) proposed a hypothetical continental source to the north of the Kabylies which fed Numidian Flysch sand southwards. An alternative interpretation requires Miocene backthrusting of Numidian Flysch deposits and portions of the Tellian units to the north over the Kabylie block (Bouillin and Glacon, 1973; Vila, 1978; Moretti et al., 1991). Biostratigraphic dating and structural analysis of the Numidian Flysch 


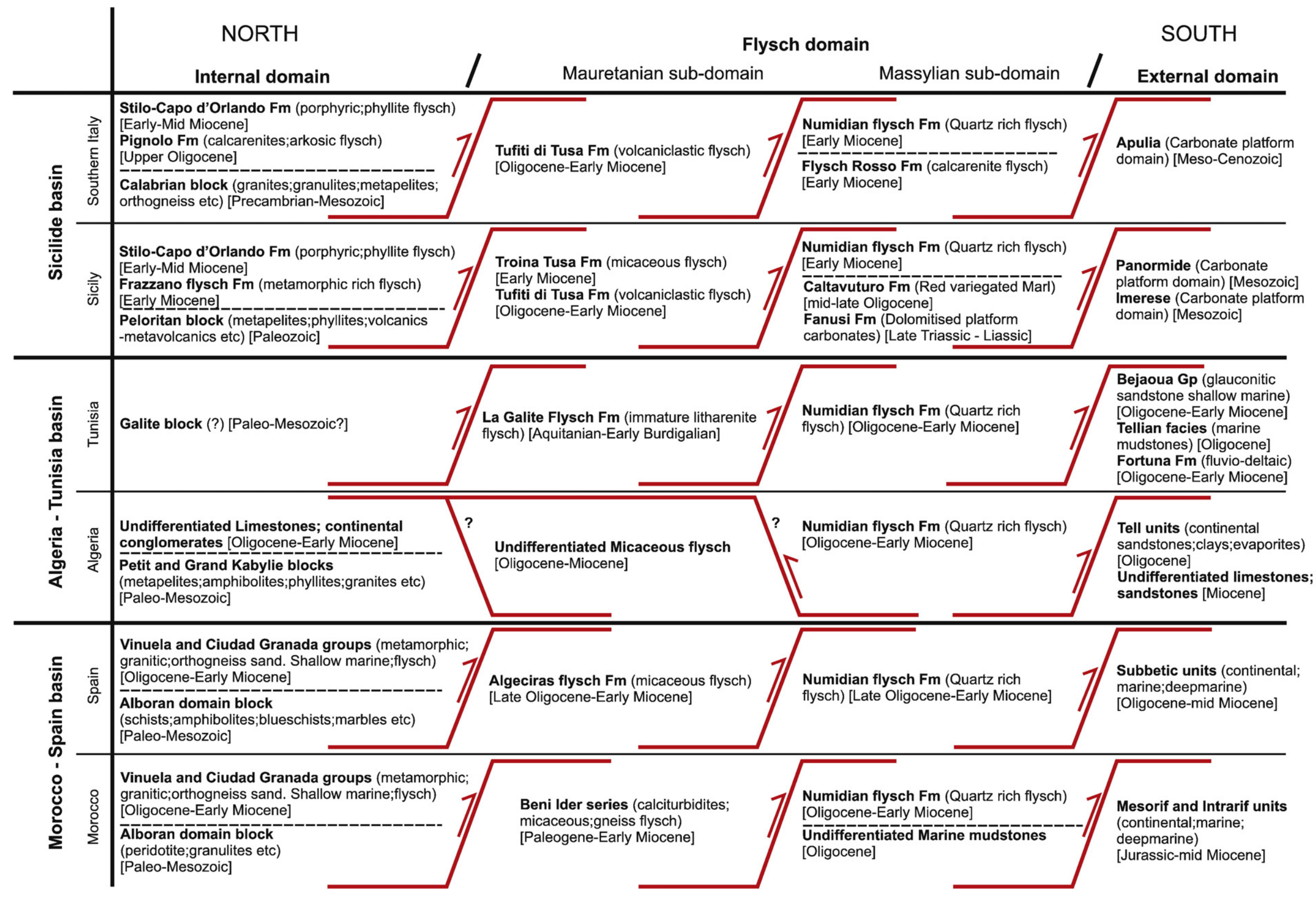

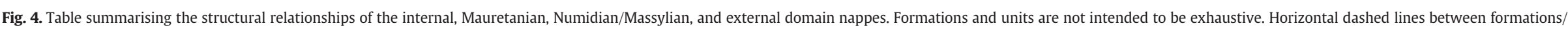
groups denote transgressive/conformable contacts. See Section 3.1 for references and details. 
and its Tellian substrate contradicts the conformable interpretation, thereby allowing for an allocthonous reinterpretation in agreement with the remainder of the basin (Magné and Raymond, 1972; Lahondére et al., 1979; Moretti et al., 1991). Géry (1983) also recognised a conformable cover to the Kabylies in northern Algeria which consisted of Oligocene to lower Miocene Limestones and continental conglomerates. The presence of continental and shallow marine facies coeval with deep marine Numidian Flysch deposition similarly suggests a backthrust configuration (Fig. 4). As with Tunisia, Andrieux et al. (1989) describes an undifferentiated micaceous flysh deposit above the petit Kabylies in north eastern Algeria.

\subsubsection{Morocco and Spain}

The Betic and Rif portions of the Alpine chain form an arc through southern Spain, the Gibraltar straits and western Morocco (CrespoBlanc and Frizon de Lamotte, 2006). In Spain, the allocthonous Alpine units are thrust upon European continental, marine, and deep marine sediments of the Subbetic zone (Alcala-Garcia et al., 2001; Lujan et al., 2006) (Fig. 4). In Morocco, Alpine nappes stack upon similar Jurassic to mid-Miocene African margin sequences of the Mesorif and Intrarif zones (Morley, 1988; Chalouan et al., 2006). Structurally above the Numidian Flysch in Spain, Palaeozoic to Tertiary metamorphic rocks (including amphibolite and blueschist facies) make up the NevadoFilabride, Alpujarride and Malaguide internal complexes which were originally part of the Alboran (AlKaPeCa) domain (Gomez-pugnaire and Fernandezsoler, 1987; Weijermars, 1991; Sanz de Galdeano et al., 1993) (Fig. 4). Within the Moroccan Rif, the Nevado-Filabride complex has no equivalent, however the Alpujarride and Malaguide complexes are represented by the Sebtide and Ghomaride units respectively (Puglisi et al., 2001; Gigliuto et al., 2004). These internal Rif and Betic units consist of an extensive series of shallow and deep marine sediments rich in metamorphic and granitic clasts (Gigliuto et al., 2004; Serrano et al., 2006) (Fig. 4). Beneath the AlKaPeCa nappes, the flysch domain is split into the Aljibe, Algeciras and Bolonia units of Spain, and the equivalent Numidian Flysch, Beni Ider and Tala Lakraa nappes of Morocco (Didon et al., 1973; Lujan et al., 2006). The Numidian Flysch crops out in the central part of the Rif chain, and the southern tip of Spanish Betics (Wezel, 1970a; Stromberg and Bluck, 1998), while in eastern Morocco the Numidian Flysch is known to lie conformably upon Palaeogene to Oligocene mudstones (Leblanc and Feinberg, 1982). Structurally above the Numidian/Aljibe nappes, the Algeciras (Spain) and Beni Ider nappes (Morocco) contain turbidite deposits with metamorphic grains and mica rich sands while the Bolonia (Spain) and Tala Lakraa units (Morocco) show a mixed succession composition of quartzose and metamorphic sands (Didon and Hoyez, 1978; Zaghloul et al., 2002; Lujan et al., 2006) (Fig. 4).

\subsection{Petrology of Numidian Flysch sandstones and mudstones}

A key characteristic of Numidian Flysch sandstones is that they are generally considered compositionally ultramature and texturally immature (i.e. Wezel, 1970b; Loiacono et al., 1983; Fornelli, 1998). This fundamental character is widespread throughout the western Mediterranean, in southern Italy (Loiacono et al., 1983; Carbone et al., 1987; Fornelli, 1998), Sicily (Broquet et al., 1963; Wezel, 1969; Caire and Duée, 1971), Tunisia (Yaich, 1992a; Riahi et al., 2007), Algeria (Moretti et al., 1988; Moretti et al., 1991), Morocco (Leblanc and Feinberg, 1982) and southern Spain (Didon et al., 1984; Stromberg and Bluck, 1998). This homogeneous character has supported the hypothesis of a single regional source area with cratonic characteristics (Carbone et al., 1987; Moretti et al., 1991; Fornelli and Piccarreta, 1997; Fornelli, 1998).

Previous studies demonstrate the Numidian Flysch to be rich in quartz (e.g. Wezel, 1969; Loiacono et al., 1983), with minor minerals reported to include feldspars, lithic grains, mica, clays, and a heavy mineral suite including zircon, tourmaline, Fe-Oxide, garnet and monazite (Gaudette et al., 1979; Fornelli and Piccarreta, 1997; Fornelli, 1998). Three published Quartz - Feldspar - Lithic (QFL) data sets from southern Italy (Loiacono et al., 1983; Carbone et al., 1987; Fornelli, 1998) show 55\% of samples plot within the quartzarenite domain, although individual populations remain well differentiated (Fig. 5A) with samples of Fornelli (1998) mostly within the subarkose field, Loiacono et al. (1983) within the sublitharenite field, and Carbone et al. (1987) within the quartzarenite field. Chemical analysis by Fornelli and Piccarreta (1997) and Puglisi (1994) also plot samples in the sublitharenite and quartzrenite fields respectivley. Algerian (QFL) data from Moretti et al. (1991) plot completely within the quartzarenite region (Fig. 5A). Similarly, observations from Sicily (Wezel, 1969), Tunisia (Yaich, 1992a), and Morocco (Leblanc and Feinberg, 1982) suggest a pure quartzarenite composition although no QFL data from either Morocco or southern Spain have been published. Italian deposits therefore show a distinction in terms of their composition currently not recognised in other localities. A strong grainsize bimodality within the quartz fraction is often recognised as a characteristic of the Numidian Flysch sandstones, typically with dominant populations of $\sim 62 \mu \mathrm{m}$ (silt), and $250 \mu \mathrm{m}$ to $2 \mathrm{~mm}$ (medium sand to granule) (Wezel, 1969; Didon et al., 1984; Fornelli, 1998). Fornelli (1998) however differentiate a compositional bimodality of grainsize in Italy, between fine lithic grains of slate, chert and phyllite, and coarse lithic grains of granitoid material.

The few studies of Numidian Flysch shales have primarily focussed upon diagenetic overprinting in the context of the Sicilide basin (Dongarra and Ferla, 1982; Balenzano and Moresi, 1992; Aldega et al., 2007). Barbera et al. (2009) however add to the provenance debate with a statistical geochemical analysis of Numidian Flysch shales in comparison to internal shales of the Troina Tusa Flysch, the early Cretaceous Monte Soro Flysch, and the upper Cretaceous Scagliose Formations of Sicily. Discriminant analysis finds internal unit chemical ratios indicative of weathered paragneisses and phyllites, typical of the Hercynian metamorphic basement of the European Peloritan block (AlKaPeCa domain). Numidian Flysch shale chemical ratios show signatures indicative of heavily weathered cratonic sandstones in direct contrast to the internal units.

As part of this study, we performed X-ray diffraction and point counting (the Gazzi-Dickinson method) on 20 samples from northern and central Sicily and 4 from northern Tunisia, with 400 counts per slide. All samples plotted in the quartzarenite zone with an average bulk composition of $\mathrm{Q}_{92}, \mathrm{~F}_{2}, \mathrm{~L}_{6}$ (Fig. 5). The ranges of the three principle minerals from all samples are $\mathrm{Q}_{91-100}, \mathrm{~F}_{0-3}$ and $\mathrm{L}_{0-10}$. Within the quartz fraction, polycrystalline grains show a range $\mathrm{Qp}_{1-68}$, and approximately equal percentages of orthoclase and plagioclase were counted throughout the samples. Our analysis reveals samples to contain minor quantities of rounded detrital glauconite, albite, anorthite, rare examples of bioclasts and a single example of rutile from Tunisia. Authigenic minerals include mica and chlorite, while abundant mud grains within the clastic matrix of many samples and not counted in our compositional analysis, represent mud rip-up clasts compatible with a turbidite origin as interpreted at outcrop.

Grainsize bimodality was also recognised, with a finer fraction of $100-300 \mu \mathrm{m}$ and a coarser fraction of $500 \mu \mathrm{m}$ to $2 \mathrm{~mm}$. The coarsest grains were found to generally consist of polycrystalline quartz (Qp) (Fig. 5B,C) while the finer grains consist of monocrystalline quartz, and minor amounts of feldspar, glauconite, mica and lithic grains. Qp grains commonly show both internal pressure dissolution and quartz overgrowths, signifying a polycyclic origin and a previous burial compaction (Fig. 5C). This polycyclicity has also been recognised in deposits of Tunisia (Fildes et al., 2010), Sicily (Wezel, 1969), Gibraltar (Lancelot et al., 1977) and Italy (Fornelli, 1998). Our outcrop studies in Sicily and Tunisia showed that facies rich in coarse grains are mainly found in poorly sorted conglomerates which are interpreted as frictional debris flow deposits and associated with large channel 


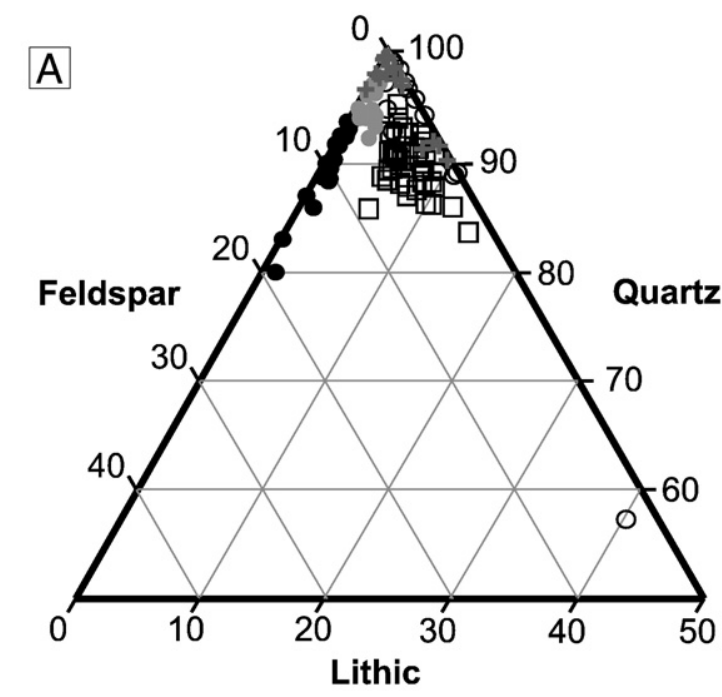

\section{Southern Italy \\ - Fornelli etal. (1998) \\ ․ Carbone etal. (1987) \\ ○ Loicano (1982)}

\author{
Algeria \\ - Moretti . (1991)
}

Data obtained for this study

+ Sicily

$\triangle$ Tunisia

$n=139$
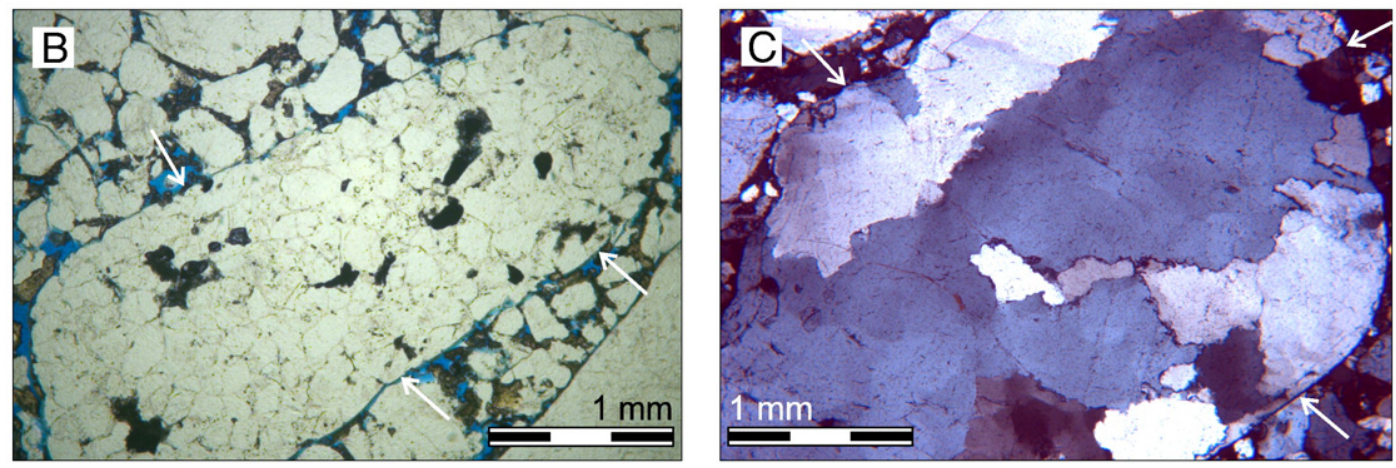

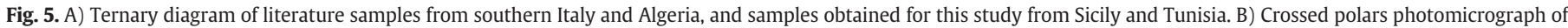

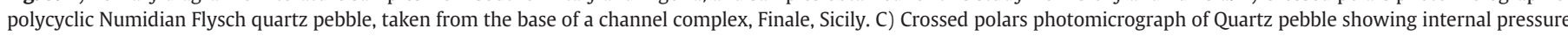

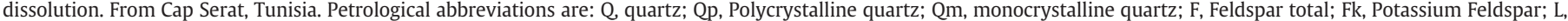
Lithic grains.

complexes (Fig. 2B). Common turbidite deposits found away from chanellised bodies (Fig. 2A) are generally finer grained such that grainsize bimodality in outcrop may therefore be attributed to the flow process involved and not directly to a distinct source or input to the basin.

Both published data, and data sourced for this study were analysed using ternary plots (QFL, QmFL or QmQpF) (see Fig. 5 for abbreviation list) and normalised binary plot methods of Chiocchini and Cipriani (1996) $(\mathrm{Fk} / \mathrm{F}: \mathrm{Q} / \mathrm{Q}+\mathrm{F}, \mathrm{Qm} / \mathrm{Q}: \mathrm{Q} / \mathrm{Q}+\mathrm{F}, \mathrm{Qm} / \mathrm{Q}: \mathrm{Fk} / \mathrm{F})$. These methods failed to resolve Individual petrofacies populations based upon sample location or age. Comparison of the new data to the published QFL data from Italy and Algeria similarly failed to resolve definable differences, although in general, Tunisian, Sicilian and Algerian samples show slightly higher quartz percentages (average $=95 \%$ ) than Italian samples which tend to contain more sedimentary lithic (Ls) or feldspar grains (average $Q=90 \%$ ).

\subsection{Palaeoflow orientations of density flow deposits}

A majority of publications concerning Numidian Flysch provenance have centred around palaeoflow orientations measured primarily from flute and sole marks on the base of density flow deposits. Palaeoflow orientations within the Numidian Flysch continue to be controversial, with published results from the same location differing by as much as $180^{\circ}$ (Wezel, 1969; Parize et al., 1986; Parize and Beaudoin, 1987; Parize et al., 1999). Furthermore, an assumption is often made that average measured palaeoflow orientations directly represent the direction of the basin floor relative to the location of flow initiation (e.g. Yaich, 1992a; Parize et al., 1999; Stow et al., 1999). On this basis several authors have proposed a northern or southern source based purely upon measured palaeoflow orientations.

A review of 140 published palaeoflow orientations from Algeria (Hoyez, 1975; Moretti et al., 1991; Laval, 1992; Vila et al., 1995), Tunisia (Hoyez, 1975; Parize et al., 1986; Parize and Beaudoin, 1987; Yaich, 1992a), Sicily (Wezel, 1969; Wezel, 1970b; Parize et al., 1986; Parize et al., 1999) and southern Italy (Carbone et al., 1987; Fornelli, 1998) suggests that no single orientation is dominant within the amalgamated dataset (Fig. 6A). 102 palaeoflow orientations presented by Hoyez (1975) from Algeria and Tunisia (their Fig. 1) demonstrate the complexity of the problem with opposite sense flow orientations measured in very close proximity.

Sole marks, the preferred flow indicator, are surprisingly rare within Numidian Flysch exposures due perhaps to their lack of preservation in coarse grained sediment. For this study we recorded data mainly from basal flute marks with some data from dune scale cross beds, ripples and slump hinge orientations in locations in the Madonie national park of northern Sicily (Fig. 6B), and at Tabarka, Cap Serat and Ras el Koran in northern Tunisia (Fig. 6C). In northern Sicily a dominant northeast direction was recorded (mean vector of $17.6^{\circ}$ ) for density flow deposits (Fig. 6C, $n=69$ ). This agrees well with data of Wezel (1969) and Wezel (1970b) but differs from Parize et al. (1986) and Parize and Beaudoin (1987) by approximately $150^{\circ}$. Data recorded for this study include flow orientations of nine large scale channel complexes in the area of Ponte Finale, Sicily (previously recognised by Johansson et al., 1998). Within the Sicilian channel 


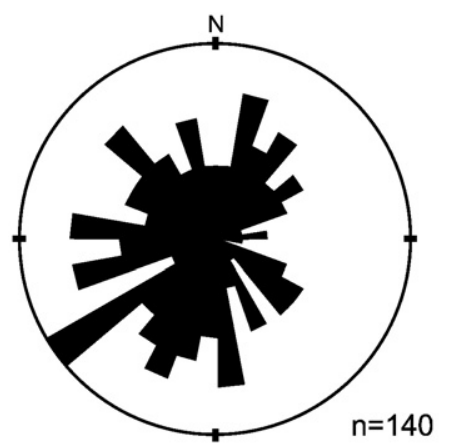

A

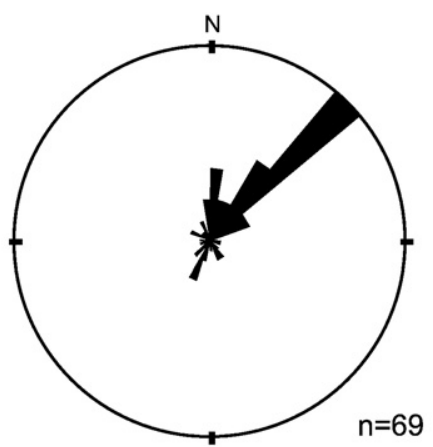

B

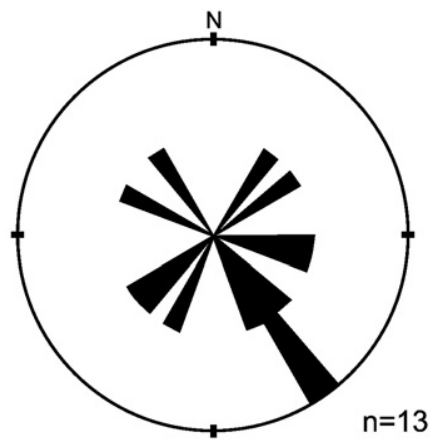

C

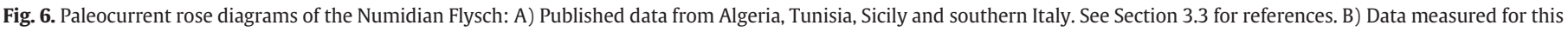
study from the Madonie region of northern Sicily. C) Data measured for this study from northern Tunisia.

complexes we measured a systematic palaeoflow swing of $90^{\circ}$ from northwest to northeast, and back to northwest (with younging) through $450 \mathrm{~m}$ of stratigraphy (Fig. 7). This is interpreted as sinuosity of the channel complex system. Mapping of the channel complexes using aerial photographs (Google earth) shows an outcrop trend towards the NW and NE in agreement with measured flow orientations. Northerly measurements from Numidian Flysch deposits of central Sicily (Contrada di Romana) are in agreement with Johansson et al. (1998) who recognised the section to be overturned.
The orientations presented here disagree with data of Parize et al. (1986) and Parize and Beaudoin (1987) by approximately $160^{\circ}$.

Measurements we recorded in Tunisia $(n=13)$ are wide ranging with a mean vector of $141^{\circ}$ (Fig. 6C). As suggested by Hoyez (1975) it cannot be said with confidence what the dominant palaeocurrent orientation is. We also observed during this field study that the Ras el Koran section, northern Tunisia undergoes a $50^{\circ}$ variation in the strike of the beds over $1.5 \mathrm{~km}$ in an east to west coastal transect, subsequently confirmed using aerial photographs (Fig. 8). It is noted that this is the

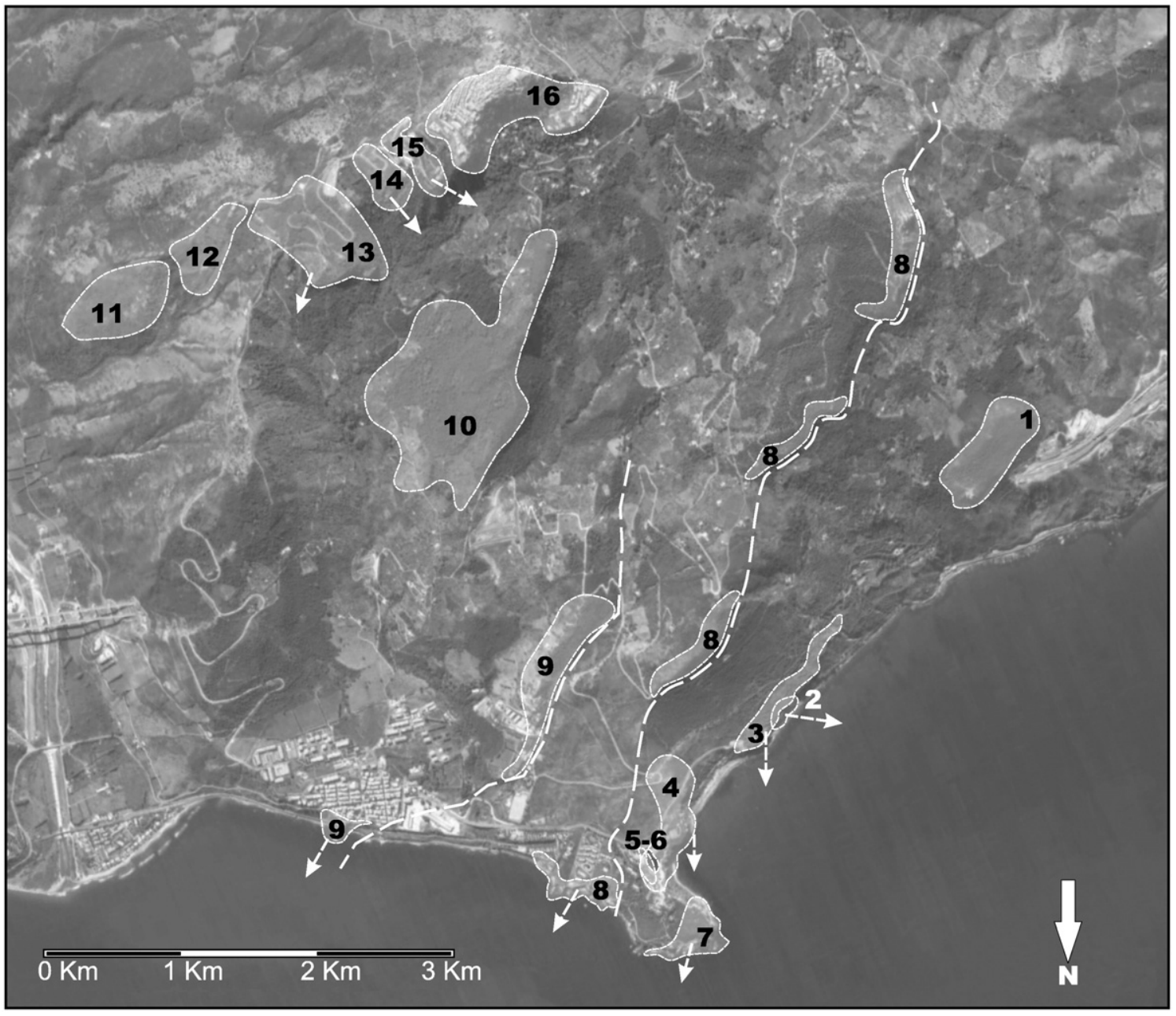

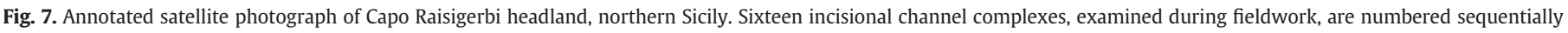

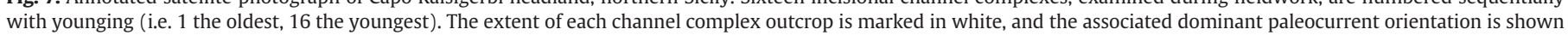
such that a systematic paleocurrent swing is observed with younging. North is towards the bottom of the image. See Section 3.3 for details. 


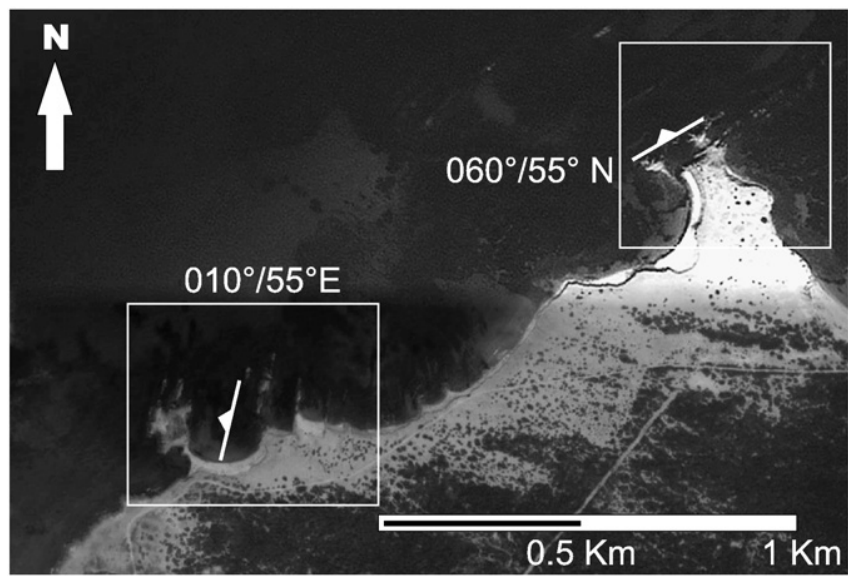

Fig. 8. An aerial photograph of the Ras el Koran section, northern Tunisia, which demonstrates a $50^{\circ}$ change in strike over $1.5 \mathrm{~km}$ of Numidian Flysch coastal section. section from which Yaich (1992a) measured southwards palaeocurrent orientations. This observation, and the general lack of a statistically significant palaeocurrent orientation, places doubt on the reliability of measurements from this locality and others.

\subsection{Detrital zircon chronology}

Detrital zircons from the Numidian Flysch of Spain, Gibraltar and Sicily have been dated by Lancelot et al. (1976) and Lancelot et al. (1977). Two populations are defined, with 90 to 95\% of zircons representing ages of $1830 \pm 100 \mathrm{Ma}$ and $5-10 \%$ of zircons representing ages of $1350 \pm 60 \mathrm{Ma}$. In both cases the populations are interpreted as having an extrusive volcanic morphology. Zircon dates from the Numidian Flysch of northern Tunisia obtained by Gaudette et al. (1975) and Gaudette et al. (1979) are found in the range of $1750 \pm 100 \mathrm{Ma}$. In comparison, Fildes et al. (2010) present much younger ages of $514 \pm 19 \mathrm{Ma}$, and $550 \pm 28 \mathrm{Ma}$ from the Numidian Flysch of Tunisia and Sicily.

Fig. 9 shows detrital zircon age ranges for the Numidian Flysch in comparison to a review of published $\mathrm{U} / \mathrm{Pb}$ zircon ages taken from

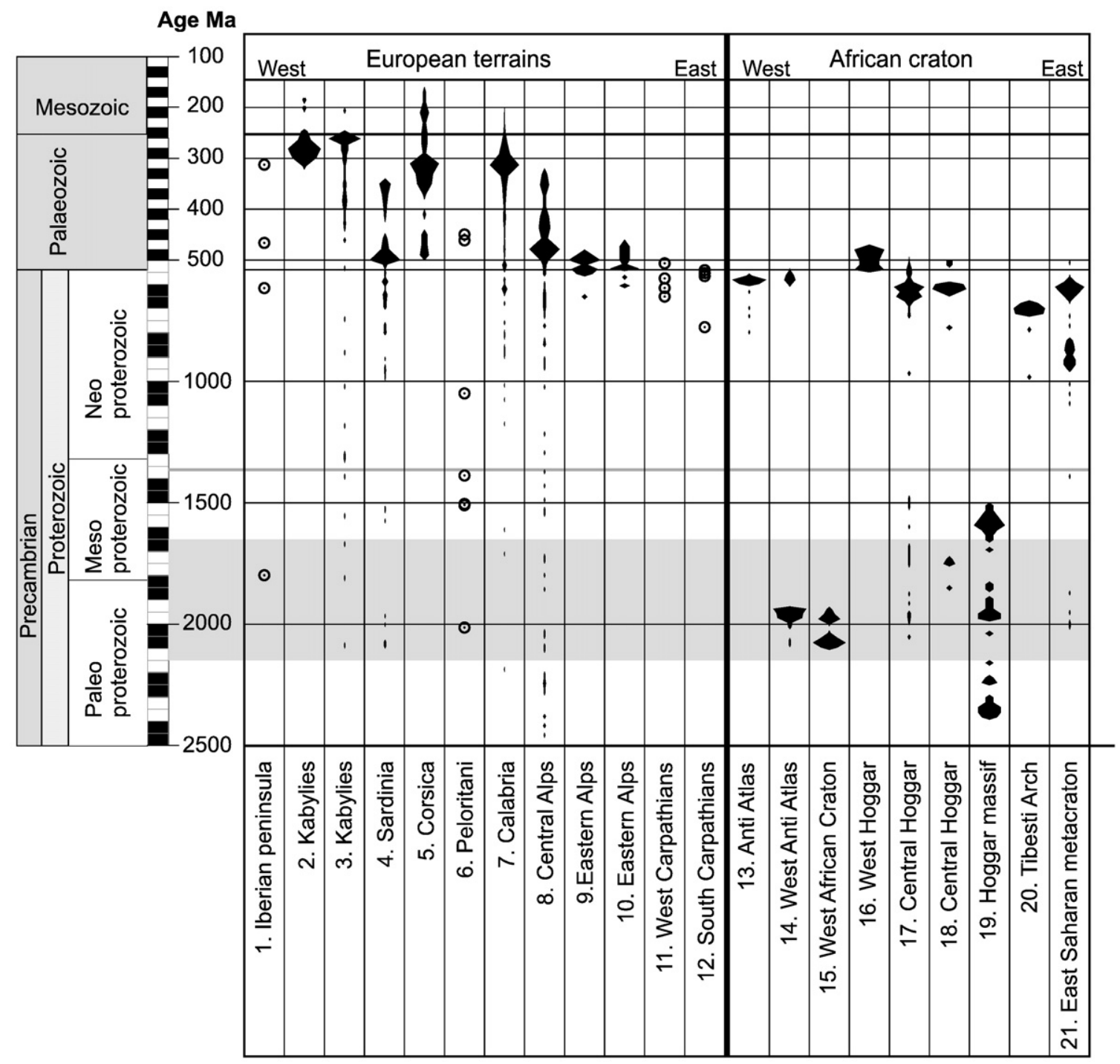

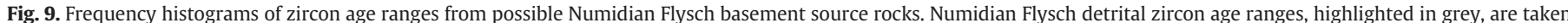

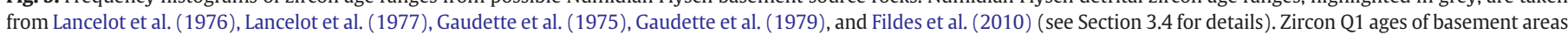

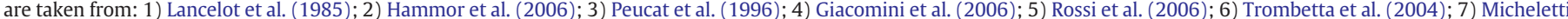

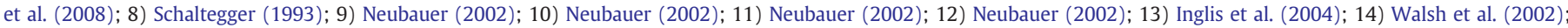

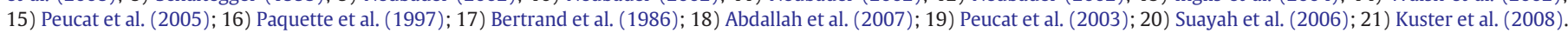
Where it was impossible to construct frequency histograms through a lack of points, circles are placed to denote age data. 
basement units around the western Mediterranean. European terrains presented include basement of the European craton from Iberia, the central Alps of Italy, the Carpathians and the Serbomacedonian massif (see Fig. 9 for references). Also presented are basement terrains of the AlKaPeCa domain, which represents the basement to the northern orogenic wedge (Calabria, Peloritan, Kabylies, Corsica, and Sardinia). Included within the African terrains are the West African craton and basement to its west, the Hoggar and Tibesti massifs, and the east African craton.

Data are presented in the format of frequency histograms such that it is apparent that basement ages from African terrains do not contain $\mathrm{U} / \mathrm{Pb}$ zircon dates younger than mid Ordovician, and a majority of dates lie within the Pan-African and Eburnian age ranges (550$650 \mathrm{Ma}$ and $2 \mathrm{Ga}$ respectively (Bertrand et al., 1986; Guiraud et al., 2005; D'Lemos et al., 2006). In contrast, European terrains show peak zircon frequencies of Cambro-Ordovician age (ie 450-550 Ma), and Carboniferous to Permian age (ie 350-250 Ma, Hercynian ages). Exceptions to this trend are Hercynian age zircons found within intrusions of the southern Sinai (Kohn et al., 1992) and within the Morocco Hercynian chain (Tahiri et al., 2007) of North Africa. While the Moroccan Hercynian deformation chain is significant, intrusions within it are relatively small and are found predominantly on the Atlantic margin, while apatite fission track data from Saddiqi et al., 2009 suggests that they were uplifted and heavily eroded in the Jurassic and early Cretaceous. For these reasons they are considered of limited importance to this study.

The AlKaPeCa domain Kabylie blocks of northern Algeria are particularly well studied using $\mathrm{U} / \mathrm{Pb}$ zircon dating, and a number of key events in their evolution are recorded. Data from the Kabylie blocks is summarised as a case study in Fig. 10. As with Fig. 9, zircon ages of up to $2.1 \mathrm{Ga}$ are recorded (Peucat et al., 1996). However, most key dates lie within the age range of the Hercynian event (225-
450 Ma (Bossière and Peucat, 1985; Peucat et al., 1996; Festa et al., 2006)) as Laurasia collided with Gondwana, which was recorded in the Kabylie blocks by a magmatic phase, regional metamorphism and subsequent crustal thinning (Schaltegger, 1993; Peucat et al., 1996; Hammor et al., 2006). The youngest dates observed relate to the Oligocene to Miocene Alpine continental collision and subsequent tectonic unroofing (Lonergan and White, 1997; Cheilletz et al., 1999; Hammor et al., 2006). The Cretaceous eo-Alpine orogeny and Alpine events are also recorded in zircons from the European Peloritani, Calabrian and Sardinian domains (Cheilletz et al., 1999; Hammor et al., 2006, and references therein).

\section{Drawing conclusions about Numidian Flysch provenance}

\subsection{Is the Numidian Flysch sourced from a single region?}

Given the vast regional extent and long duration of Numidian Flysch deposition, the question arises as to whether the Numidian Flysch represents a single source region. Given the many suggestions of both a European and African source, the possibility remains that sediment is sourced from both the north and south. Laval (1992) also suggested a new source area to the north of the Kabylie block (AlKaPeCa) in order to account for complications arising from the Numidian Flysch being interpreted to sit conformably above the internal Kabylie blocks (see Section 3.1.2).

The similarity of the Numidian Flysch petrofacies throughout the western Mediterranean suggests that the Numidian Flysch is a formation sourced from either a single region, several regions with a very similar lithology, or distant source regions coupled with a transport history long enough to remove minerals less stable than quartz (e.g. Garzanti et al., 2007). Comparison of Numidian Flysch mineralogy with contemporaneous units of the Mauretanian flysch

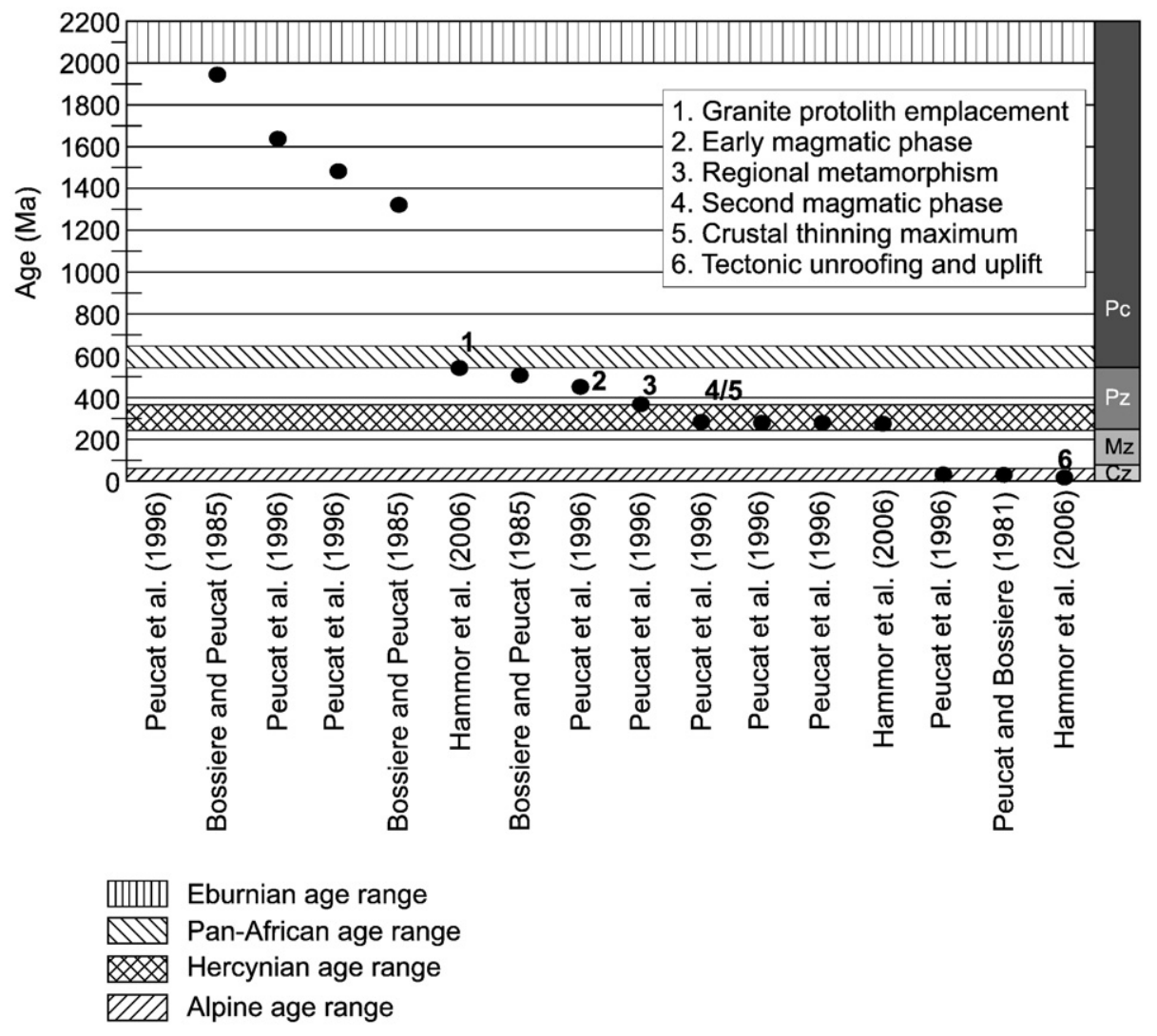

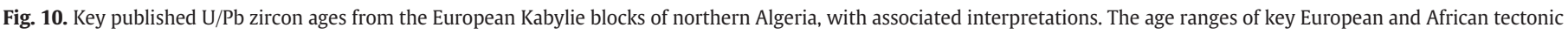
events are included: Pc, Precambrian; Pz, Paleozoic; Mz, Mesozoic; Cz Cenozoic. 
subdomain also reveal a stark difference, with northern deposits enriched in volcanic and metamorphic clasts (e.g. the micaceous and immature sandstones of Algeria, Tunisia and Sicily (Laval, 1992; Belayouni et al., 2010) and the Tufiti di Tusa formation of Sicily and Italy (<30\% quartz) (Pescatore et al., 1992; de Capoa et al., 2002). This implies a gross disparity of source region with the consistently ultramature Numidian Flysch sandstones. Minor percentages of volcanic and metamorphic clasts in Numidian Flysch sands from southern Italy (Fig. 5A) have been interpreted in terms of foredeep mixing of the Numidian Flysch, and a metamorphic/volcaniclastic facies sourced from Sardinia and Corsica (Fornelli and Piccarreta, 1997), rather than representing source region lithology. The depositional location of southern Italian deposits is also rather distinct from that of North Africa, representing the southern border of the Lucanian ocean, and thereby creating the potential for mixing of axial sediments from the Lucanian foredeep with those of the MFB (Fornelli and Piccarreta, 1997; Fornelli, 1998). Regardless of indicating a specific source area, the north-south compositional disparity provides compelling evidence that the Numidian Flysch facies throughout the chain is sourced from one region (whether northern or southern) with the immature arenaceous facies of Mauretanian subdomain sourced from a separate region. Coupled with this, the inability to differentiate sandstone samples from Algeria, Tunisia and Sicily using ternary and binary plots, suggests that the Numidian Flysch does not represent sediment sourced from both the northern and southern margins of the basin concurrently. It is interpreted therefore that the compositional homogeneity indicates a single source for the Numidian Flysch sandstones.

\subsection{A northern or southern source?}

As with the homogenous petrological characteristics of the Numidian Flysch (Fig. 5), the structural position of Numidian Flysch nappes is similar throughout the entire Alpine chain (Fig. 4). A trend from south to north of African margin units, Numidian Flysch nappes, immature arenaceous and argillaceous flysch nappes, and European crystalline basement is recognised, and constrained most clearly in Sicily. African units consist of carbonate platforms in Italy and Sicily, continental to marine Tellian facies in Tunisia and Algeria, and similar rocks in Morocco. Immature arenaceous and argillaceous units thrust above the Numidian Flysch are recognised as the Tufiti di Tusa and Troina Tusa Formations of Sicily and southern Italy, the Galite Flysch in Tunisia, undifferentiated micaceous flysch of northern Algeria, and metamorphic clast rich sandstones of the Algeciras, Beni Ider, Bolonia and Tala Lakraa units in Morocco and Spain. Therefore, a location of deposition between the Mauretanian subdomain and the African margin units is well resolved. Confirmation in Tunisia of an allocthonous contact between the Numidian Flysch and African Tellian units also places the Numidian Flysch in the same external position of the MFB. The nature of the contact between the Numidian Flysch and the internal Kabylie block in Algeria mirrors this debate, and biostratigraphic dating suggests a backthrust contact between the two units (Magné and Raymond, 1972; Lahondére et al., 1979). Given the similarity of the petrofacies and structural position of the Numidian Flysch throughout the rest of the chain, placing the Numidian Flysch basin to the north of the Kabylie block in Algeria as suggested by Laval (1992) is considered highly unlikely. A backthrust geometry which places the Numidian Flysch above the Kabylie block would again place Numidian Flysch nappes in a position similar to the remainder of the Alpine chain (Fig. 4). The recognition of a continental and shallow marine environment, coeval with Numidian Flysch deposition in the Kabylie domain (Raymond, 1976; Géry, 1983) also affirms this interpretation. The recognition of micaceous flysch by Andrieux et al. (1989) above the petit Kabylie also suggests a very similar structural sequence as in the rest of the chain. Despite the Algerian debate, it is noticeable that studies concerned primarily with correlating stratigraphic and tectonostratigraphic units of the entire MFB consistently point to an external location for the Numidian Flysch and an internal position for Mauretanian flysch, and by default an African and AlkaPeCa source region respectively (Puglisi, 1987; Guerrera et al., 1993; Balogh et al., 2001; Puglisi et al., 2001; de Capoa et al., 2002, 2004; Guerrera et al., 2005; de Capoa et al., 2007).

The regional definition of Mauretanian and Massylian subdomains based upon contrasting petrofacies further suggests that the Numidian Flysch source region is different to that of the internal Mauretanian flysch. QFL analysis of the reviewed data plots Numidian Flysch sandstones within the cratonic source zone as suggested by Folk (1951) and Dickinson and Suczek (1979). Their large regional extent, homogeneity and polycyclic nature indicate reworking of a laterally extensive quartzarenite sandstone, again indicative of a cratonic region. Statistical geochemical analysis of Numidian Flysch shales (Barbera et al., 2009) similarly finds a compositional contrast against the mudstones of Mauretanian units, with a composition indicative of a highly weathered cratonic sandstone source which is in good agreement with the sandstone modal analysis. In contrast, the mineralogy of Mauretanian flysch sandstones appears well constrained to the AlKaPeCa domain. Igneous grains including phyllites and granites, reported in Mauretanian flysch deposits from southern Spain, Morocco and southern Italy match lithologies of the AlKaPeCa domain, and are interpreted as sourced from them (Mazzoleni, 1991; Fornelli and Piccarreta, 1997; De Galdeano et al., 2006). Mauretanian sandstones rich in volcanic grains are similarly interpreted as being sourced from the AlKaPeCa magmatic arc to their immediate north (Ferla and Alaimo, 1976; Pescatore et al., 1992; Balogh et al., 2001; Puglisi et al., 2001; Puglisi, 2008). Analysis of Mauretanian unit shales in Sicily similarly assigns a Peloritan block (AlKaPeCa) provenance, interpreted as paragneiss and phyllite source rocks (Barbera et al., 2009). Despite these lithological connections strongly suggesting an African source for the Numidian Flysch quartz, various authors have recognised relatively minor amounts of quartz sands in the transgressive cover to the AlKaPeCa domain (Bossière and Peucat, 1986). Critelli et al. (2008) describes Triassic fluviatile redbeds from the internal zones of the Betic, Magrebian and Apennines which are quartzarenitic or quartzolithic. They transgress upon, and are derived from Hercynian AlKaPeCa basement blocks, and are subsequently enriched in quartz through weathering processes. Caire and Duée (1971) also compared thermoluminescence curves from Numidian Flysch quartz with sediments of the Kabylie and Peloritan blocks, concluding that Sardinia represents an alternative source region for quartz pebbles within the Numidian Flysch.

$\mathrm{U} / \mathrm{Pb}$ zircon data is perhaps the most unequivocal indicator of provenance available in this study. Providing a representative volume of the source rock is weathered, and given that specific age populations cannot be preferentially removed during transport, it is expected that sediment sourced from any terrain will contain a representative frequency distribution of zircon ages as recorded by the host rock(s). Sampling of localised areas may however not reflect regional age populations, and bias associated with preferential sampling of certain areas, due to factors such as accessibility, may distort regional populations. The three main age populations within the Numidian Flysch (Palaeoproterozoic, upper Mesoproterozoic, and upper Neoproterozoic to Cambrian) define a source in which: (a) The Eburnian and Pan-African events are represented; (b) Neither the Hercynian or Alpine events are represented.

While African basement contains only Cambrian and Precambrian zircon ages, some European basements reviewed contain minor frequencies of Precambrian zircons, and relatively high frequencies of Pan-African age zircons (550-650 Ma) (Fig. 9). Lancelot et al. (1985), Schaltegger (1993), Micheletti et al. (2008) and Fiannacca et al. (2008) all interpret Pan-African zircons from European metasediment basement in Iberia and Calabria to be representative of detrital sediments sourced from the African craton and transported north 
during Gondwanan times, rather than a European record of the PanAfrican event. A case study review of the Kabylie blocks of northern Algeria demonstrates that despite the presence of Precambrian zircons, a majority of zircons are within the age ranges of the Hercynian and Alpine events (Fig. 10). This profile has similarly been recognised in the Peloritan and Calabrian blocks (Fig. 9), and effectively exempts these AlKaPeCa domain blocks as suitable source regions, despite the presence of some quartz rich material. Lancelot et al. (1985) did however record Hercynian age zircons from the immature Troina Tusa Flysch Formation of Sicily (termed the Gréso micacé in that study), deposited within the Mauretanian subdomain and contemporaneous with the Numidan Flysch (Section 3.1.1 and Fig. 4). In contrast, data from the African craton show a very good general correlation to Numidian Flysch detrital data. In particular, dates from the Moroccan fringes of the west African craton and the Hoggar (Bertrand et al., 1986; Paquette et al., 1997; Walsh et al., 2002; Peucat et al., 2003, 2005; Abdallah et al., 2007) correlate well with the $1830 \pm 100$ Ma population of Lancelot et al. (1977) from Spain and Sicily, the $1750 \pm 100$ population of Gaudette et al. (1975) and Gaudette et al. (1979) (Tunisia), and the $514 \pm 19 \mathrm{Ma}$, and $550 \pm$ $28 \mathrm{Ma}$ ages of Fildes et al. (2010). The minor population of extrusive volcanic zircons centred upon $1350 \pm 60 \mathrm{Ma}$ is a common date found in central and southern Africa (Milner et al., 1995; Jerram et al., 1999; Becker et al., 2006 etc), but is however not well matched in the data we have reviewed in North Africa.

Given the Cambrian to Precambrian constraints of detrital zircon ages, the cratonic petrofacies of both Numidian Flysch sandstones and Numidian Flysch shales, and the external position within the nappe pile, a northern AlKaPeCa source is effectively negated. Overall, this provides a clear correlation of African sourced Numidan quarzarenites (the Massylian subdomain) and AlKaPeCa sourced deep marine clastics with a compositionally immature character (the Mauretanian subdomain). However, while our review gives no dominant conclusion to the palaeocurent debate, several works consisting of more localised data sets do give consistent orientations leading to interpretations, primarily, of southerly directed flow from a northern source (e.g. Parize et al., 1986; Parize and Beaudoin, 1987; Laval, 1992; Parize et al., 1999; Fildes et al., 2010). The apparent contradiction between these results and the bulk of evidence suggesting a southern source, is addressed below (Section 4.3).

\subsection{The viability of the palaeocurrent debate}

There is an underlying assumption within the palaeoflow debate that the average flow orientation is indicative of the direction from flow source (e.g. shelf or slope environment) to the location of deposition (eg the lower slope or basin floor). In this manner, the direction of flow transport denotes the dip direction of the basinal slope. This interpretation has previously been challenged by Hoyez (1975), and a number of arguments exist that challenge this assumption which is inherent to the palaeoflow debate.

The large scale palaeocurrent study of Hoyez, $1975(n=102)$ and the data presented here $(n=140)$ suggest that on a basin scale there is no statistically significant average palaeoflow orientation (Fig. 6A). A majority of studies based upon palaeocurrent data focus upon specific localities however, and it remains possible that location specific studies record a local palaeodip-slope, which over the length of the $2000 \mathrm{~km}$ basin could be highly variable. A review of analogue basins suggests that flow orientation within foreland basins is indeed highly variable and does not represent the slope dip direction. Examples of the Quaternary Barbados accretionary prism, the Tertiary Alpine, Apennine and Pindos basins, the Cretaceous Magellanes basin in Chile, and the Permian Arkoma basin from the central United States, show that a majority of flow orientations measured at outcrop run parallel to the basin strike and not perpendicular to it (Ross and Houseknecht, 1987; Sutherland, 1988; Faugères et al., 1993; Sinclair,
1997; Avramidis and Zelilidis, 2001; Mutti et al., 2003; Cibin et al., 2004; Shultz et al., 2005). An arcuate geometry as found in the Tertiary Alpine basin would therefore produce palaeoflow variations that mirror variations in basin strike, with a systematic $120^{\circ}$ change throughout the length of the basin (Sinclair, 1997). The Sicilide portion of the MFB is interpreted during the Oligocene to have $\mathrm{a}>50^{\circ}$ arcuate geometry (Fig. 12) and a similar variation in flow direction may therefore be expected. Studies of flow deposits which are proximal to the basin margins however, often document orientations which are at a high angle to the basin strike (Cainelli, 1994; Sinclair, 1997; Avramidis and Zelilidis, 2001; Eschard et al., 2003) and these deposits represent flows deposited on the basin slope rather than the basin floor. The context of flow orientation measurements is therefore vital prior to interpretations of basin architecture. Furthermore, on a scale substantially less than that of the basin, density flow systems in slope settings demonstrate a high degree of variability. The systematic $90^{\circ}$ variability of Numidian Flysch palaeoflow observed within a $5 \mathrm{~km}$ wide, $450 \mathrm{~m}$ thick channel system in northern Sicily illustrates this problem (Fig. 7), and indeed observation of modern slope systems demonstrates that many channel systems can be highly sinuous in nature (Peakall et al., 2000; Deptuck et al., 2007; Wynn et al., 2007). Submarine slope systems are also often highly structured, as in the passive margin examples of Angola (Fraser et al., 2005; Gee et al., 2007), the Niger delta (Heinio and Davies, 2007), and the Nile delta (Samuel et al., 2003). In these examples, salt or mud diapirism, regional tectonics, en masse gravitational sliding of the entire slope system, and the local effects of mass wasting can have a considerable impact upon the transport direction of both channel systems and unconfined density flows (Haughton, 2000; Shultz and Hubbard, 2003; Ferry et al., 2005). Channel system orientations in active margin settings are similarly observed to be controlled primarily by thrustfault segmentation, giving rise to ponded basins in the hanging wall synform, in which reflection of turbidity currents from topography is increasingly being recognised (Faugères et al., 1993; Huyghe et al., 2004; Estrada et al., 2005; Mutti et al., 2009).

A further level of complication arises during emplacement of Numidian Flysch nappes upon the African foreland. Numidian Flysch channel outcrops in central Sicily have been shown to be overturned (Johansson et al., 1998), and in Ras el Koran, northern Tunisia, the Numidian Flysch stratigraphy is observed to change strike by $50^{\circ}$ (Fig. 8) suggesting that structural emplacement has involved rotation. Indeed, several palaeomagnetic studies in Sicily and southern Italy (Channell et al., 1990; Oldow et al., 1990; Speranza et al., 2003; Monaco and De Guidi, 2006) have demonstrated a $70^{\circ}$ clockwise rotation of the nappe pile from the Langhian (immediately post Numidian Flysch) until the end of continental collision in the late Tortonian (Monaco and De Guidi, 2006) while in central Italy an anticlockwise rotation has been described (Maffione et al., 2008). Nappe pile rotations of between $55^{\circ}$ and $76^{\circ}$ have also been reported for the Moroccan and Spanish sectors of the MFB (Lonergan and White, 1997 and references therein).

Despite sedimentary complications, the effect of both basin and outcrop scale tectonics renders palaeocurrent evidence highly unreliable. Given the considerable problems, the provision of a northern AlKaPeCa source in certain localities can be largely dismissed. Constraints by zircon chronology, sandstone and mudstone petrology, and location within the nappe pile, suggest that an African craton source remains the only viable option.

\section{Implications of a constrained African source}

\subsection{Possible African source regions}

The Continental Intercalaire (Ivaldi, 1977; Lancelot et al., 1977; Moretti et al., 1991) and Pharusian series (Moretti et al., 1991) of western and central Africa, the Nubian sandstone of the Sirt basin in 
Libya (Wezel, 1970a; Johansson et al., 1998) and Permo-Triassic and Cambro-Ordovician continental sandstones of southern Tunisia (Gaudette et al., 1975, 1979) have all been suggested as source terrains for the Numidian Flysch (Fig. 3). A review of zircon age ranges (Fig. 9) suggests that the western Anti Atlas of Morocco, the West African craton and the Hoggar massif all provide a good correlation with Eburnian age detrital zircons of the Numidian Flysch. Zircon ages of the west and central Hoggar also provide a match to Pan-African age detrital zircons from the Numidian Flysch. The minor population of volcanic Numidian Flysch zircons centred upon $1350 \pm 60 \mathrm{Ma}$ is a common date found in central and southern Africa (Milner et al., 1995; Becker et al., 2006) but not in North Africa. The possibility remains that a Mesoproterozoic volcanic source exists in North Africa that has yet to be sufficiently dated, else long distant transport from central Africa must be invoked. While these cratonic basement terrains are likely candidates for the origin of Numidian Flysch zircons, the polycyclic nature of Numidian Flysch sediments require that they do not represent first cycle sediments but reworked sandstones which have previously undergone burial compaction (see Section 3.2) (Fig. 5C).

The oldest abundant quartz rich sandstones in North Africa are first cycle mature quartz sands (75-100\% quartz) of CambroOrdovician age found in Morocco, Algeria, Libya and east to the Persian Gulf (Avigad et al., 2005; Ghienne et al., 2007). They contain zircons from the entire Proterozoic and upper Archean, with suites of mainly Neoproterozoic age (0.5-1.25 Ga), upper Palaeoproterozoic to mid Mesoproterozoic (1.6-2.0 Ga) and upper Neoarchean to lowermost Palaeoproterozoic (2.4-2.8 Ga), in very good agreement with Numidian Flysch zircon age ranges (Fig. 9) (Avigad et al., 2003, their Fig. 3; Avigad et al., 2005). The sands were eroded during continental scale uplift of basement during the Pan-African orogeny (Avigad et al., 2005) and sustained significant reworking towards the north during the Cambro-Ordovician glaciation (Ghienne and Deynoux, 1998; Moreau et al., 2005). The Pharusian is a similar series which infills topography generated during transpression and Neoproterozoic intrusion events in the western Hoggar and west African craton (Caby, 2003). Fluvial, alluvial and deltaic sediments were fed into molassic basins (Ahmed and Moussinepouchkine, 1987), while volcanic greywackes were fed into deeper basins (Caby et al., 1977).

The original definition of the term Continental Intercalaire describes continental sediments deposited throughout Algeria, Tunisia and Libya, deposited between the Namurian (lower Carboniferous) and upper Cenomanian marine series (Kilian, 1931). Continental Intercalaire sediments crop out between the Hoggar and the west African craton, between the Hoggar and the Algerian Atlas belt, and in the Ghadames basin of Libya and Tunisia (Lefranc and Guiraud, 1990). Significant quartz rich sandstones are also found in the lower Triassic and Early Cretaceous continental sediments of the Oued Mya basin, central and northern Algeria, and in Early Cretaceous sediments of west Algeria and Libya (Lefranc and Guiraud, 1990). Triassic sediments of the Berkine basin (Algeria) filled topography of the Hercynian unconformity, and contain thick fluvial sequences with an average composition of $88 \%$ quartz (Rossi et al., 2002). These Triassic sandstones are interpreted to be sourced from pre-Hercynian sequences, and basement rocks of the Hoggar (Rossi et al., 2002).

Numidian Flysch sediment shares both zircon and petrological characteristics with sediments of the Cambro-Ordovician and Continental Intercalaire sandstones. Both of these extensive series are interpreted as being sourced from the Hoggar massif and other cratonic basement. It seems likely therefore that the Numidian Flysch may be a reworking of these sandstone series which today crop out in southern Tunisia and central Algeria. While it is not possible to further constrain individual source areas, the Numidian Flysch may be considered a reworking of African continental series by Cenozoic northwards draining fluvial systems.

\subsection{Location and timing of Numidian Flysch sediment input}

\subsubsection{Timing of deposition versus basin tectonics}

Outcrop maps compiled by Wezel (1970a) suggest that Numidian Flysch sediments are concentrated in northern Morocco, and in a zone from eastern Algeria to southern Italy (Fig. 1).

Oligocene to mid-Miocene Numidian Flysch deposition is observed throughout the western Mediterranean (Lahondére et al., 1979; Moretti et al., 1991; Torricelli and Biffi, 2001) although important diachreneity is observed. In the Algerian-Tunisian and SpanishMoroccan sections of the basin, deposition occurs from the lower or mid Oligocene, while in the Sicilide basin deposition commences from the Oligocene-Miocene transition, some 5 Myrs later. In the AlgerianTunisian portion of the basin, deposition ceases by the Burdigalian, while continuing until the mid-Miocene throughout the remainder of the basin. The Sicilide basin thus only records early to mid-Miocene age sediments (Carbone et al., 1987; Faugères et al., 1992).

Southwards migration of the AlKaPeCa domain and the related allocthony since the Oligocene (Cassola et al., 1991; Puglisi, 2008) have displaced Numidian Flysch deposits significantly from their depositional locations (Geel and Roep, 1998; Speranza et al., 2003). Moroccan deposits were thrust westwards in front of the Alboran plate while Sicilide deposits were thrust eastwards and then southwards by as much as $200 \mathrm{~km}$, in front of the Peloritan and Calabrian blocks (Geel and Roep, 1998; Speranza et al., 2003; de Capoa et al., 2007) (Fig. 12). The basin closed in Algeria and Tunisia as the continental Kabylie and Galite blocks docked with the African margin from the latest Oligocene until the Burdigalian (Caby, 1996; Cheilletz et al., 1999; Mauffret et al., 2004). Numidian Flysch deposition in Algeria and Tunisia therefore ended earliest, in the latest Aquitanian to earliest Burdigalian, correlating with the time of basin closure (Figs. 11, 12).

Continental collision and basin closure in the Moroccan and Sicilide sections of the basin occurred much later than Algeria and Tunisia, being roughly contemporaneous in the Serravelian (de Capoa et al., 2004, 2007) (Fig. 11). While deposition in Morocco and Spain occurs throughout the Oligocene and Miocene, in the Sicilide basin the onset of deposition correlates with the timing of closure of the Tunisian and Algerian sector of the basin, suggesting that sediment was routed laterally away from the closing basin towards Sicily (Fig. 12). Sicilide deposition ends in the latest Burdigalian to Langhian (Didon et al., 1984; Faugères et al., 1992), roughly coincident with the end of Spanish and Moroccan deposition.

\subsubsection{The location and style of sediment input}

One of the key arguments against an African source region has been the lack of a suitable sediment pathway from the African craton to the southern margin of the MFB (Caire and Duée, 1971; Hoyez, 1975; Parize et al., 1999). Wezel (1970a), originally suggested a Nubian source from the Sirt basin in Libya, and invoked sediment bypass across the Libyan continental shelf through a channel system. Such a system has however not been observed. Structural juxtaposition of the deep marine Numidian Flysch with sandstones of the shallow marine Bejaoua Group in Tunisia (Fig. 4), has led to the suggestion that feeder channels were present in northern Tunisia, perhaps also responsible for propagating sediments towards Algeria along the basin axis (Wezel, 1970a; Wildi, 1983). In eastern Tunisia, the Fortuna Delta, suggested as a candidate for sediment feeding (Benomran et al., 1987; Johansson et al., 1998), has subsequently been questioned due to its east and south palaeoflow towards the Pelagian basin (Vanhouten, 1980), its compositional immaturity (Yaich, 1992b) and dating, which suggests pebble rich horizons do not correlate with clastic periods within the Numidian Flysch basin (Yaich et al., 2000). Detrital zircon data from the Fortuna Delta shows ages of $1698 \pm 67$ Ma (Fildes et al., 2010) which, although significantly different from the Numidian Flysch detrital zircons of Fildes et al. 


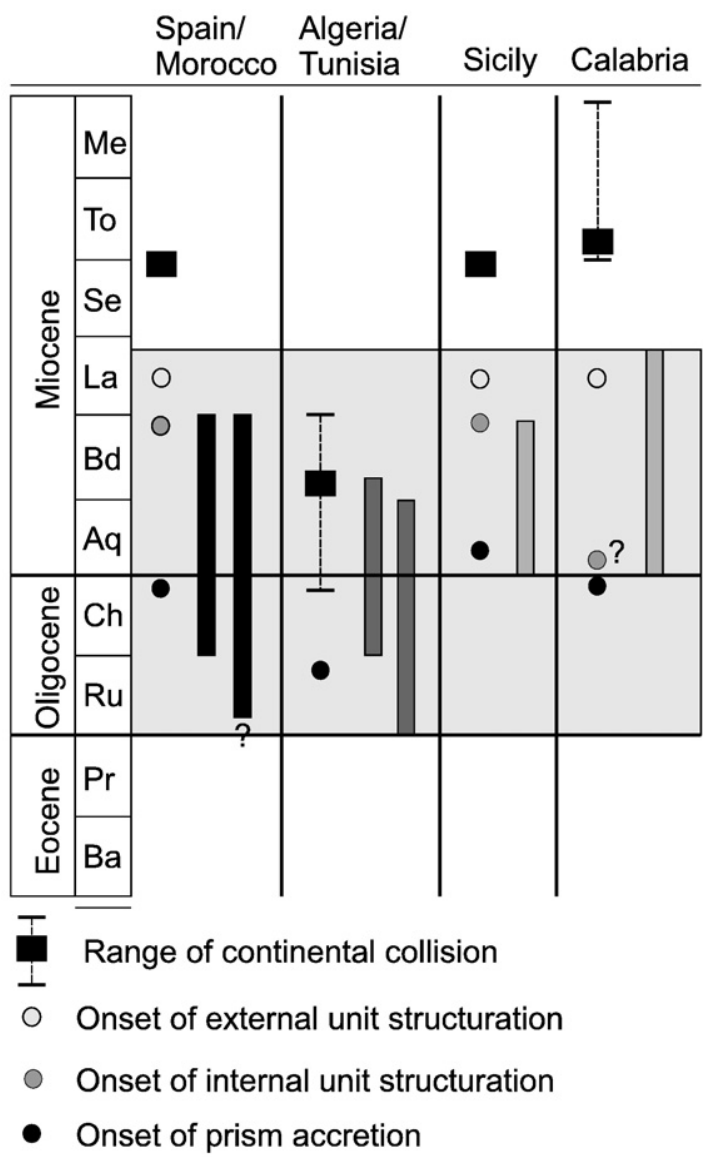

Fig. 11. Age ranges of Numidian Flysch deposition in comparison to regional tectonic events. Spain, Gibraltar, Morocco data from: Didon et al. (1984); Stromberg and Bluck (1998); de Capoa et al. (2007). Algeria, Tunisia data from: Magne and Raymond (1972); Lahondére et al. (1979); Moretti et al. (1991); Caby (1996); Cheilletz et al. (1999); Torricelli and Biffi (2001); Mauffret et al. (2004); Guerrera et al. (2005); Boukhalfa et al. (2009). Sicilide basin data from: Cello and Mazzoli (1998); Bonardi et al. (2003); Artoni (2007); de Capoa et al. (2007); Iannace et al. (2007); Maffione et al. (2008); Putignano and Schiattarella (2008), and biostratigraphic data obtained for this study (see Section 2).

(2010), are similar to Numidian Flysch data from Lancelot et al. (1977) and Gaudette et al. (1979). The interpretation of structureless massive sandstones filling submarine channels and produced by sustained, steady (or near-steady) state flows in northern Sicily (Johansson et al., 1998), also implicitly requires hyperpycnal input from a river to the deep basin. In Algeria, Vila et al. (1995) has suggested a major sediment input point from the interpretation of deep marine channelised sandstones in Numidian Flysch deposits. In Morocco, Geel and Roep (1998) point out that westward migration of the Alboran plate may have detached Numidian Flysch deposits from an Algerian or Tunisian input point, such that a separate feeder system is not required. The feeder system models proposed in these studies require that established and isolated fluvial drainage systems transported sediment into the basin, although with the exception of the Fortuna Delta, large scale contemporaneous fluvial or deltaic deposits have yet to be reported. It remains possible that other such deposits are buried beneath allocthonous units of the Alpine chain or else removed by the forebulge unconformity, however this remains a problem for the African source model.

An increasing number of outcrop, morphological, and seismic studies are recognising submarine fan systems that were active during relative or eustatic highstand conditions (Mitchum and Van Wagoner, 1991; Clark, 1995; Weber et al., 1997, 2003; Pattison, 2005; Carvajal and Steel, 2006; Covault et al., 2007; Shanmugam, 2008; Uroza and
Steel, 2008) such that low stand fan systems represent only a portion of the deep marine sequence stratigraphic model. In transgressive to relative highstand conditions, a range of mechanisms have been suggested to loft sediment from a shelf environment and transport it basinwards without the need of direct shelf feeder systems. Studies by Shanmugam (2008), Stow and Mayall (2000), El Kadiri et al. (2006a) suggest that flooding of the shelf during the initial transgression, and storm events, tsunami and longshore currents during highstand conditions are capable of debouching large volumes of sediment from the shelf to the slope.

Fig. 13 correlates Numidian Flysch depositional periods with the global Cenozoic oxygen isotope curve of Zachos et al. (2001) and the sea-level curves of Haq et al. (1987) and Van Sickel et al. (2004). Negative oxygen isotope trends are indicative of global cooling from the Palaeocene-Eocene thermal maximum (Abreu and Haddad, 1998; Zachos et al., 2001; Ernst et al., 2006; Sluijs et al., 2008). The Eocene then records a low order cooling, which is reversed in the late Oligocene similarly recorded by negative oxygen isotope trends (Zachos et al., 2001) (Fig. 13). Numidian Flysch deposition therefore occurred during a low order glacioeustatic transgression, recognised in outcrop studies throughout the entire western Mediterranean (Grasso et al., 1994; El Kadiri et al., 2006b) including Tunisia (Jeddi, 1994), Morocco (Maate et al., 1995; Hlila et al., 2004; Serrano et al., 2006), Sicily (Grasso et al., 1994; Pedley and Renda, 1998) and Corsica (Ferrandini et al., 1998). Further to this, the onset of prism accretion in the north of the basin, began in the Oligocene, correlating with the beginning of foreland basin flexural loading. As the accretionary prism migrated southwards, basin subsidence increased until Numidian Flysch deposits became structured. The Miocene therefore represents a time of maximum slope subsidence (through the proximity of the prism and the corresponding flexural loading), and thus the deepest water according to foreland basin flexural subsidence models (Sinclair, 1997; DeCelles and Giles, 1996 etc).

The Numidian Flysch therefore broadly correlates with times of high sea level, such that prograding fluvio-deltaic systems, typically interpreted to transport sediment across the subaerially exposed shelf to the basin during lowstand conditions (Woolfe et al., 1998; Posamentier, 2001; Catuneanu, 2002), may not have existed during Numidian Flysch deposition. A linear source of many relatively minor fluvial drainage systems may therefore be the preferred option, depositing sediment directly upon the submerged shelf environment, prior to current and storm reworking on to the slope, as is the case in present day California (Paull et al., 2005; Covault et al., 2007). On a basin scale, the laterally continuous distribution of Miocene age Numidian Flysch outcrops between Algeria and Tunisia, and between Sicily and southern Italy (Figs. 1, 12), would appear to represent a relatively linear source, or else isolated local input points with axial migration of density flows along the basin floor. Further characterisation of either a slope or basin floor depositional location, may help to clarify this point, however a linear source would help explain the lack of contemporaneous, large scale fluvial and deltaic systems reported in North Africa.

\subsection{Controls upon Numidian Flysch sedimentation}

\subsubsection{Eustatic controls}

As discussed previously (Section 5.2.2), sequence stratigraphic models typically suggest that lowstand conditions play a major role in activating deep marine fan systems. Lowstand conditions generating subaerial exposure of the shelf will allow incision and progradation of fluvial systems which may then transport sediment to the shelf edge where direct feeding into the basin is possible. In addition to having major implications upon the style of sediment input, this has major implications upon the timing of deposition. The correlation of Numidian Flysch deposition with a low order glacioeustatic highstand and transgression in the Oligocene-Miocene (Section 5.2), suggests 
however that contrary to these models, the onset of Numidian Flysch deposition is not controlled by sediment progradation across the shelf during a lowstand systems track.
At present, a majority (but not all) of highstand deepwater clastic system examples are recognised associated with the large continental margins of the western and eastern United States, the west coast of

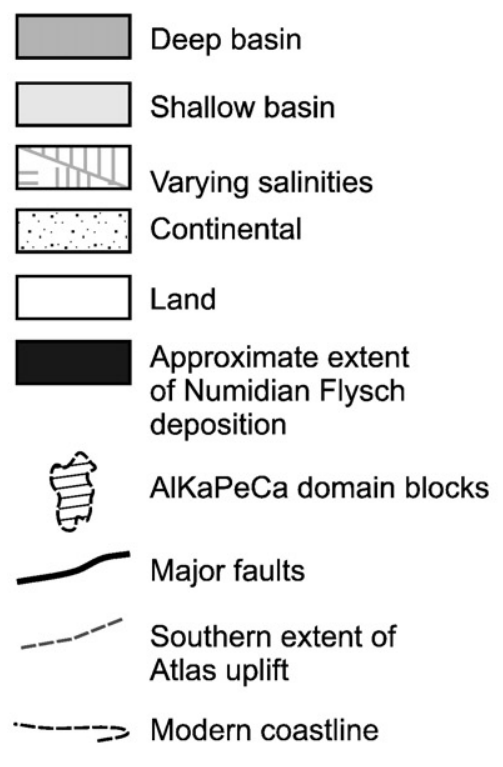

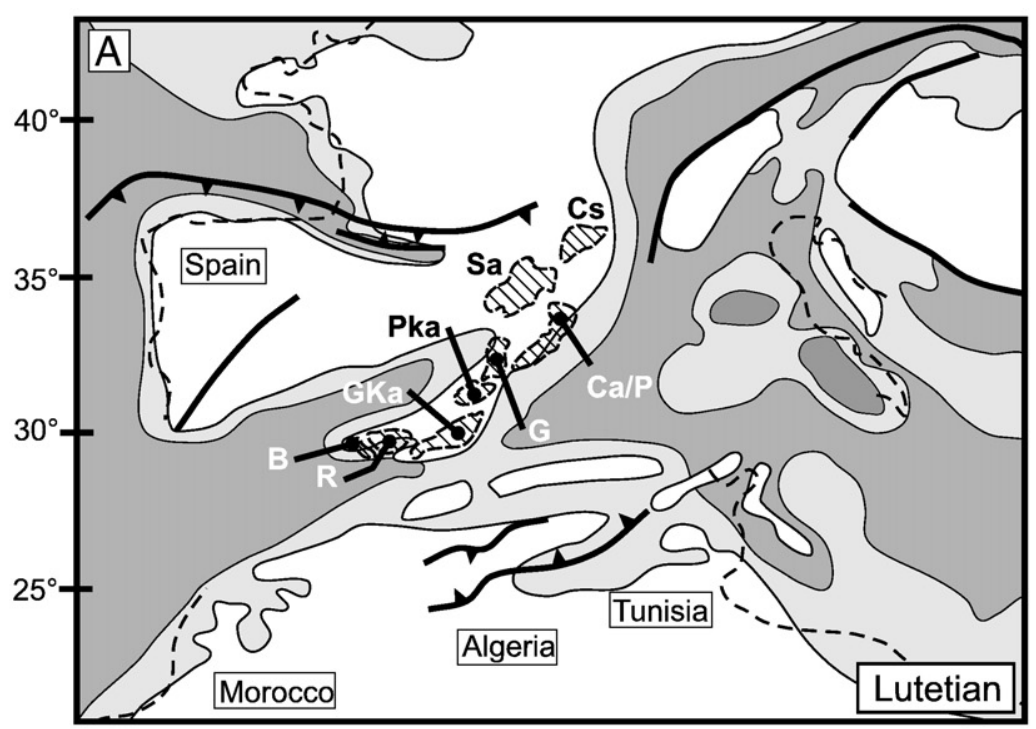
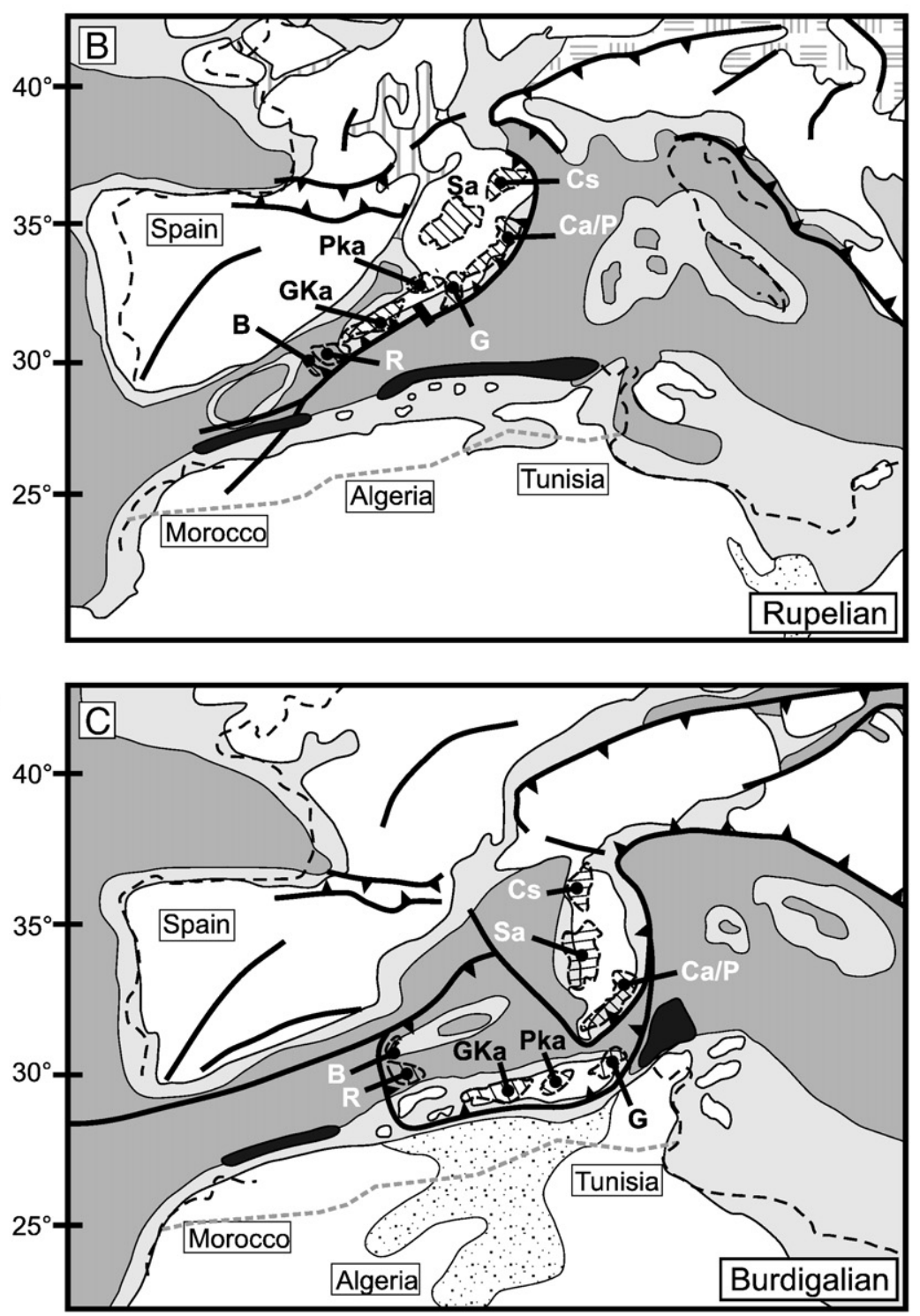
$\delta^{18} \mathrm{O}$ (parts per thousand)

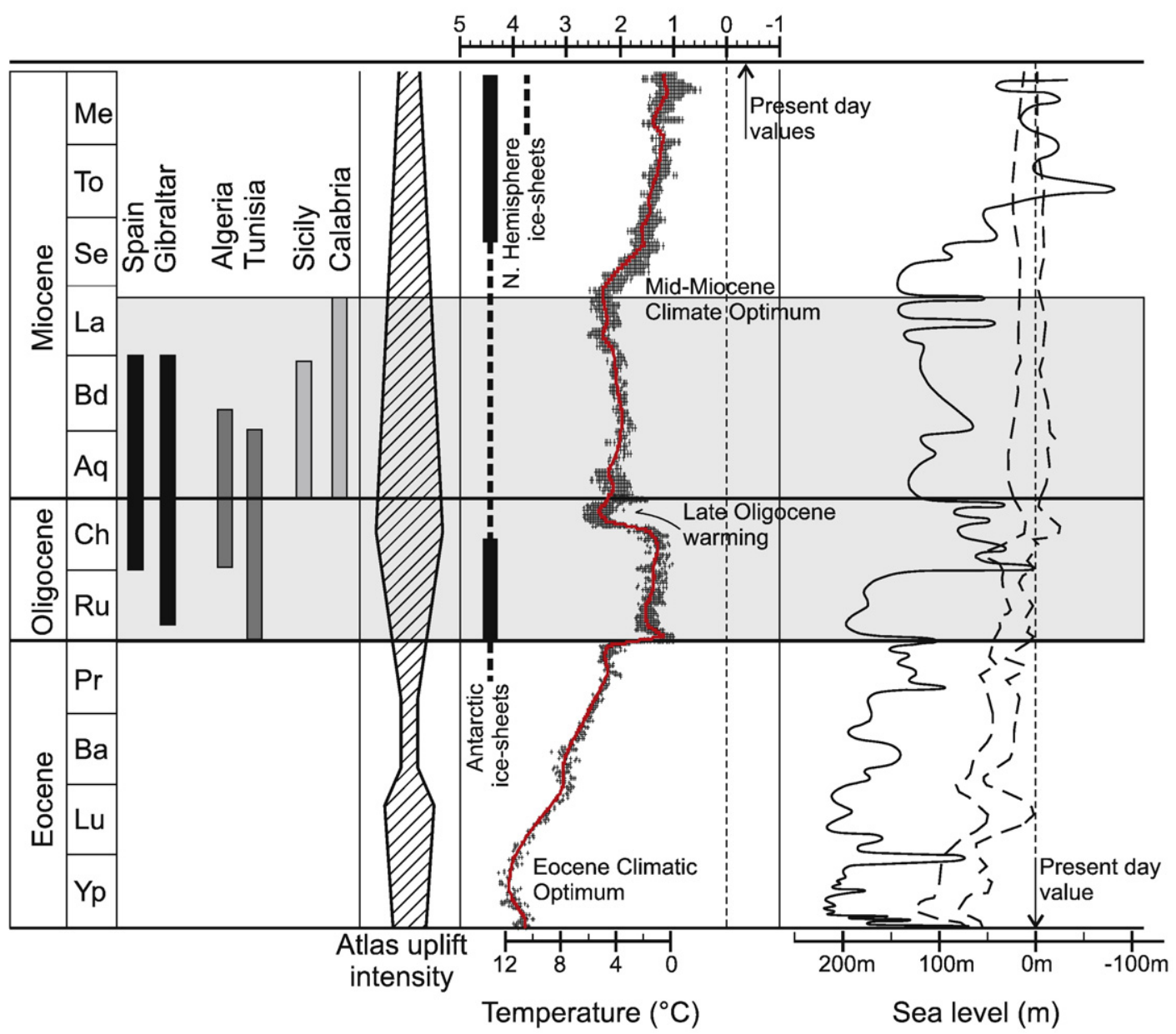

\section{$\longrightarrow$ Averaged $\delta^{18} \mathrm{O}$ curve. Redrawn from Zachos et al. (2001) \\ $\longrightarrow$ Short term eustatic curve of Haq et al. (1987) \\ 二 = $\quad$ R2 sealevel curve (Max-min envelope) of Van Sickel et al. (2004)}

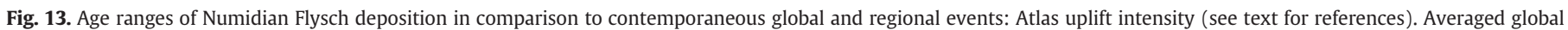

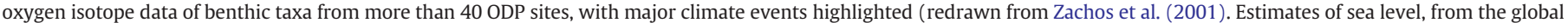
eustatic chart of Haq et al. (1987) and Van Sickel et al. (2004).

Africa and the Bengal fan. In studies of the California borderland highstand fan system, Covault et al. (2007) suggest that a narrow shelf and high sediment input that is reworked by longshore currents during highstand conditions, forces clastic sediments along the shelf to canyon heads at the shelf break. Thus, during highstand conditions, the sedimentation rate is calculated as being significantly greater than the equivalent lowstand rate. Carvajal and Steel (2006) however studied a moderately wide Maastrichtian shelf system from Wyoming (United states) in which a high sediment supply was able to overcome the effects of eustacy and substantial shelf width. Given that Numidian Flysch deposition is directly out of phase with low order lowstand events, it is suggested that they do not exert a significant control upon Numidian Flysch sedimentation. The effects of higher order eustatic cycles upon sedimentation and depositional architec- tures remain unknown however, and require higher resolution correlation between individual clastic packages and relative sealevel signals. The detailed and well dated stratigraphy required for such an analysis is currently not available throughout a majority of the MFB.

\subsubsection{Tectonic controls}

The Atlas event generated uplift in response to an early phase (pre Alpine) of Africa-Europe convergence from the late Cretaceous (Piqué et al., 2002), and has been attributed as accommodating between 17 and $45 \%$ of the total Cenozoic shortening (Gomez et al., 2000). Uplift occurred throughout the whole of North Africa coeval with deposition of the Numidian Flysch. Uplift in Morocco is recognised in several phases including the upper Cretaceous, a paroxysmal Lutetian phase,

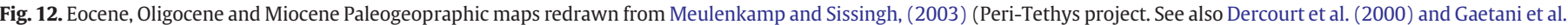

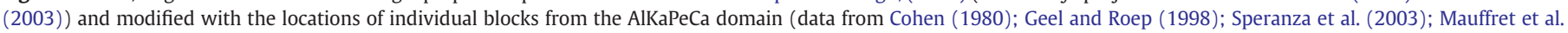

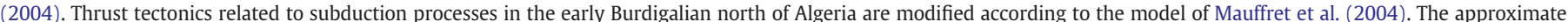

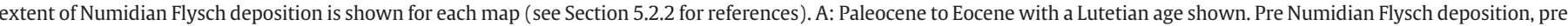

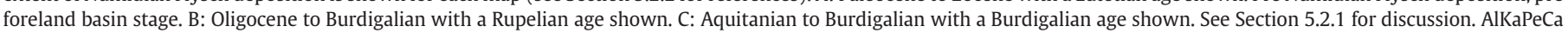
block abbreviations are: B, Betic; R, Riff; Cs, Corsica; Sa, Sardinia; Ca/P, Calabria and Peloritan; G, Galite block; Pka, Petit Kabylie; Gka, Grand Kabylie. 
and a Lutetian to Bartonian phase (Benest and Bensalah, 1995). In Algeria, rapid uplift which produced molasse deposits, is interpreted to have occurred in the late Lutetian (Benest and Bensalah, 1995; Bracene and Frizon de Lamotte, 2002). In northern Tunisia, work on the Medjez-el-Bab anticline similarly constrains a Maghreb wide uplift event in the mid to late Eocene (Masrouhi et al., 2008), while in central Tunisia, uplift effected platform carbonate sediments are late Palaeocene to early Eocene in age (El Ghali et al., 2003). A later Oligocene phase, regarded as the peak uplift event in Morocco is also evidenced throughout the Maghreb in the high Atlas mountains of Morocco (El Harfi et al., 2001; Ait Brahim et al., 2002) and in Tunisia and Algeria (Frizon de Lamotte, 2005). Structures described include broad folds, oblique strike-slip faulting and a predominance of thrust faults (Burollet, 1991; Benest and Bensalah, 1995; Frizon de Lamotte, 2005; Khomsi et al., 2006), which terminate in the south at a physiographic boundary called the Saharan flexure (Piqué et al., 2002) (Fig. 12). A correlation of Atlas uplift events to the onset of Numidian Flysch deposition (Fig. 13) demonstrates that deposition occurs during an increase in uplift rates throughout North Africa, with peak uplift rates during deposition in the Moroccan, Algerian, and Tunisian sectors of the basin. Substantial and prolonged uplift across the whole of North Africa, would certainly generate the shedding of sediment with a cratonic sandstone petrofacies towards the North African margin, and must be considered a major factor in controlling the timing of onset of Numidian Flysch clastic deposition.

\subsubsection{Climatic controls}

The Eocene-Oligocene boundary at which Numidian Flysch deposition first occurs, marks the start of intermittent ice sheets in Antarctica and the trend towards an ice house world (Miller et al., 1991). A consequent increase in continental drainage is reported from many locations.

During the Oligocene and Miocene, a gradation from carbonate to clastic dominated deposition is recognised throughout North Africa. In a review of African margin basins, Benomran et al. (1987) cites several significant clastic Formations which commence at this time; sandstone filled channels and troughs are known to cut Oligocene carbonates in the eastern and north-western sectors of the Sirt basin of Libya (Selley, 1968). In Tunisia, mid Oligocene sandstones of the Fortuna Delta conformably cover Eocene shales and shallow water carbonates (Vanhouten, 1980), while in the Pelagian basin to the east, sandy carbonates of the Al Mayah Formation and sandstones of the Sousse Formation give way eastwards to the deep marine Djerba Formation. In southern Sicily, Montanari (1986) reports that the northwest Hyblean plateau varies from limestones and marls to calcarenites and sandy argillaceous sediments in the early Miocene. Reviewing Algerian continental sediments from the Atlas domain of northern Algeria, Kheidri et al. (2007) similarly shows a clastic input in the Oligocene with undifferentiated clastic sediments succeeding limestone, marl and evaporate units of mid-Cretaceous to Eocene age. In Malta, John et al. (2003) interpret increased African continental runoff in the early to mid Miocene based upon a switch from limestone to marls and an increase in Kaolinite clays at the expense of Smectite.

Studies of North African palaeogeography in the Oligocene and Miocene confirm that the climate was considerably wetter than at present times, resulting in increased drainage. Fossil records of Crocodilians in Libya and Tunisia constrain a tropical environment for the Miocene and perhaps as early as the Eocene-Oligocene boundary (Markwick, 1998; Llinás Agrasar, 2004). Similarly, evolutionary diversification of the mammalian order Macroscelidea (the Elephant Shrew) suggests that North Africa (the current Rif-Tellian domain) retained a tropical environment until the mid-late Miocene boundary (Douady et al., 2003). It has also been suggested that North Africa may have contained Miocene tropical forest and savannah in some areas despite a very poorly preserved continental climate record (Fluteau et al., 1999 and references therein; Burgoyne et al., 2005).

Relatively little is also known about Cenozoic drainage patterns of North Africa, although the palaeo river Nile is known to have prograded northwards across Egypt in the Oligocene, with major delta deposition occurring in the mid-Miocene (Burke and Wells, 1989 and references therein). In Algeria and Libya, a now extinct Miocene river system termed the Eoshabi also drained the Hoggar and Tibesti massifs northwards towards the Gulf of Sirt (Goudie, 2005). Fluteau et al. (1999) also demonstrate through a grid point mathematical model that the northern front of the African monsoon lay approximately at the palaeolatitude of the uplifted Hoggar region of southern Algeria $\left(22^{\circ} \mathrm{N}\right)$, considerably to the north of the present day position. Rainfall of up to $2 \mathrm{~mm}$ /day is predicted for monsoon months over the North African margin. John et al. (2003) also suggests that short lived Miocene glacial events (Mi global events events of Miller et al., 1991) punctuating the generally cooling climate served to push the intertropical convergence zone northwards towards the North African margin resulting in increased rainfall and continental drainage. Ruddiman et al. (1989) suggest furthermore that uplift of the Atlas belt (see Section 5.3.2) would have the capacity to form barriers to oceanic moisture fluxes in North Africa from at least the early Miocene, which may presumably enhance drainage of the uplifting Atlas belt.

Few studies have been carried out in order to detect the effect of climate upon North African drainage at this time, however dramatic coeval increases in sedimentation from offshore Angola have similarly been attributed to global cooling and specific Mi glacial events (Lavier et al., 2001). Therefore, while uplift of the Atlas belt of North Africa coincides with the start of Numidian Flysch deposition, global climatic conditions may also play a substantial role in the drainage of the uplifting belt.

\section{Conclusions}

The 50 year controversy surrounding the provenance of the Numidian Flysch has had a detrimental effect upon the understanding of both the Maghrebian Flysch Basin architecture and controls upon Numidian Flysch deposition. A comprehensive review of published data, integrated with data obtained for this study, suggests that the African craton is the only suitable candidate source region of clastic material for the Numidian Flysch. The northern source hypothesis is not supported by these data, and is therefore not viable. Given the significant geographic extent and duration of the Numidian Flysch system, a solution to the provenance problem and the placing of the Numidian Flysch within a basinal context, has the potential to offer significant insights into the controls upon Cenozoic drainage of the North African margin. A North African source region also constrains the Numidian Flysch to be a passive margin sequence, rather than a flysch deposit (sensu stricto).

Petrological and zircon analysis constrain the polycyclic, quartzarenite petrofacies of Numidian Flysch sandstones to a large cratonic source region that has zircons of Eburnian and Pan-African age, but none of Hercynian and Alpine age. Around the western Mediterranean realm, North Africa is the only regional domain that satisfies these requirements. A review of the location of Numidian Flysch nappes within the Alpine thrust belt confirms the Numidian Flysch to have been deposited in a southern, external location (i.e. proximal to the North African margin). Immature sandstones of the northern Mauretanian subdomain have characteristics including a volcanic, granite and metamorphic clast rich petrofacies and a Hercynian age zircon suite. The location of Mauretanian subdomain nappes within the Alpine chain, constrains a depositional location to the north of the Numidian Flysch, while their lithofacies and zircon suite show a strong affinity with the basement blocks of the northern AlKaPeCa 
domain. A clear distinction of northerly and southerly sourced flysch deposits is therefore observed.

The suggestion of a northern source from uniform palaeocurrent evidence is considered highly unlikely given the observation of sinuous channel systems in Sicily, variable thrust belt strike in Tunisia, and published palaeomagnetic studies which demonstrate large horizontal rotations of the nappe pile during emplacement. An extensive review of available palaeocurrent data similarly indicates no statistically significant flow direction throughout the basin. Moreover, analogue foreland basin systems typically show a dominant palaeoflow that is parallel to basin strike, such that the inherent assumption in the palaeoflow argument, that flow orientation is indicative of the direction from source to basin, is also considered invalid.

Recognition of Numidian Flysch depositional diachroneity from biostratigraphic dating, both published and obtained for this study, constrains three main sedimentary input areas, in Morocco; Algeria and Tunisia; and south of Sicily. A review of regional basin tectonic events and their timings demonstrates a shifting of depocentre from Tunisia towards the Sicilide basin in the Aquitanian, controlled by diachronous closure of the basin. In general, the location and timing of sediment deposition shows a close agreement with published tectonic models and palaeogeographies of the MFB.

In contrast to conventional sequence stratigraphic models of submarine fans systems, timing of deposition of the Numidian Flysch sandstone is not in phase with sea-level falls or lowstand events. On a low order timescale, this rules out eustacy as a controlling factor upon the timing of Numidian Flysch deposition. Timing of deposition does however show a very good correlation with Atlas uplift events throughout North Africa. Furthermore, climatic studies evidence increased North African continental drainage and marine clastic deposition, occurring contemporaneously with Numidian Flysch deposition. The Numidian Flysch therefore represents a large scale Cenozoic drainage system on the North African passive margin, in which sediment was sourced from a tectonically uplifted hinterland, while the timing of deposition appears to be controlled by a combination of hinterland uplift intensity and global climatic variations.

\section{Acknowledgements}

Our thanks go to Prof. Dorrik Stow for introducing us to the Sicillian field area and to Stuart Marsh (Anadarko Exploration) for kindly funding a trip to Tunisia. We also thank the following Oil companies who sponsor the North African Research Group; Anadarko Exploration, BG group, ConocoPhillips, Hess, Maersk Oil and Gas, Occidental, Petro-Canada, Pluspetrol, Repsol YPF, RWE Energy and Wintershall. Finally, we are particularly thankful to D. Puglisi and S. Critelli for constructive reviews of the manuscript and Andrew Miall for editorial assistance.

\section{References}

Abdallah, N., Liegeois, J.P., De Waele, B., Fezaa, N., Ouabadi, A., 2007. The Temaguessine Fe-cordierite orbicular granite (Central Hoggar, Algeria): U-PbSHRIMP age, petrology, origin and geodynamical consequences for the late Pan-African magmatism of the Tuareg shield. Journal of African Earth Sciences 49, 153-178.

Abreu, V.S., Haddad, G.A., 1998. Glacioeustatic fluctuations; the mechanism linking stable isotope events and sequence stratigraphy from the early Oligocene to middle Miocene. Special Publication - Society for Sedimentary Geology 60, 245-259.

Ahmed, A.A.K., Moussinepouchkine, A., 1987. Lithostratigraphy, sedimentology and evolution of 2 intramontane molassic basins of the Pan-African range - SeriePourpree de Lahnet, northwest of Hoggar, Algeria. Journal of African Earth Sciences 6 (4), 525-535.

Ait Brahim, L., Chotin, P., Hinaj, S., Abdelouafi, A., El Adraoui, A., Nakcha, C., Dhont, D., Charroud, M., Sossey Alaoui, F., Amrhar, M., Bouaza, A., Tabyaoui, H., Chaouni, A., 2002. Paleostress evolution in the Moroccan African margin from Triassic to present. Tectonophysics 357 (1-4), 187-205.
Alcala-Garcia, F.J., Martin-Martin, M., Lopez-Galindo, A., 2001. Clay mineralogy of the Tertiary sediments in the internal subbetic of Malaga Province, S Spain; implications for geodynamic evolution. Clay Minerals 36 (4), 615-620.

Aldega, L., Corrado, S., Grasso, M., Maniscalco, R., 2007. Correlation of diagenetic data from organic and inorganic studies in the Apenninic-Maghrebian fold-and-thrust belt: a case study from eastern Sicily. Journal of Geology 115 (3), 335-353.

Andrieux, J., Djellit, H., Aubouin, J., 1989. Structure de la Petite Kabylie occidentale (Algerie); flyschs "ultra" et flyschs externes. Comptes Rendus de l'Academie des Sciences, Serie 2, Mecanique, Physique, Chimie, Sciences de l'Univers, Sciences de la Terre 309 (11), 1191-1196.

Artoni, A., 2007. Growth rates and two-mode accretion in the outer orogenic wedgeforeland basin system of Central Apennine (Italy). Bollettino Della Societa Geologica Italiana 126 (3), 531-556.

Avigad, D., Kolodner, K., McWilliams, M., Persing, H., Weissbrod, T., 2003. Origin of northern Gondwana Cambrian sandstone revealed by detrital zircon SHRIMP dating. Geology 31 (3), 227-230.

Avigad, D., Sandler, A., Kolodner, K., Stern, R.J., McWilliams, M., Miller, N., Beyth, M., 2005. Mass-production of Cambro-Ordovician quartz-rich sandstone as a consequence of chemical weathering of Pan-African terranes: environmental implications. Earth and Planetary Science Letters 240 (3-4), 818-826.

Avramidis, P., Zelilidis, A., 2001. The nature of deep-marine sedimentation and palaeocurrent trends as-evidence of Pindos foreland basin fill conditions. Episodes 24 (4), 252-256.

Balenzano, F., Moresi, M., 1992. Le peliti del Flysch Numidico nell'Appennino Meridionale. Mineralogica et Petrographica Acta 35, 139-156.

Balogh, K., Cassola, P., Pompilio, M., Puglisi, D., 2001. Petrographic, geochemical and radiometric data on Tertiary volcano-arenitic beds from the Sicilian Maghrebian Chain: volcanic sources and geodynamic implications. Geologica Carpathica 52 (1), 15-21.

Barbera, G., Lo Giudice, A., Mazzoleni, P., Pappalardo, A., 2009. Combined statistical and petrological analysis of provenance and diagenetic history of mudrocks: application to Alpine Tethydes shales (Sicily, Italy). Sedimentary Geology 213 (1-2), 27-40.

Becker, T., Schreiber, U., Kampunzu, A.B., Armstrong, R.A., 2006. Mesoproterozoic rocks of Namibia and their plate tectonic setting. Journal of African Earth Sciences 46 (1-2), $112-140$.

Belayouni, H., Brunelli, D., Clocchiatti, R., Di Staso, A., Hassani, I.E.E.A.E., Guerrera, F., Kassaa, S., Ouazaa, N.L., Martín, M.M., Serrano, F., Tramontana, M., 2010. La Galite Archipelago (Tunisia, North Africa): stratigraphic and petrographic revision and insights for geodynamic evolution of the Maghrebian Chain. Journal of African Earth Sciences 56 (1), 15-28.

Benest, M., Bensalah, M., 1995. L'Eocene continental dans l'avant-pays alpin d'Algerie; environnement et importance de la tectogenese atlasique polyphasee. Bulletin du Service Geologique de l'Algerie 6 (1), 41-59.

Benomran, O., Nairn, A.E.M., Schamel, S., 1987. Sources and dispersal of mid-Cenozoic clastic sediments in the central Mediterranean region. In: Lentini, F. (Ed.), Atti del convegno su; Sistemi avanfossa-avampaese lungo la Catena Appenninico-Maghrebide. Memorie della Societa Geologica Italiana. Societa Geologica Italiana, Rome, Italy, pp. 47-68.

Bertrand, J.M., Michard, A., Boulier, A.-M., Dautel, D., 1986. Structure and U/Pb geochronology of central Hoggar (Algeria); a reappraisal of its Pan-African evolution. Tectonics 5 (7), 955-972.

Bonardi, G., Giunta, G., Ligouri, V., Perrone, V., Russo, M., Zuppetta, A., Ciampo, G., 1980. Osservazioni sull'evoluzione dell'Arco Calabro-Peloritano nel Miocene inferiore: la Formazione di Stilo-Capo d'Orlando. Bollettino Della Societa Geologica Italiana 99, 365-393.

Bonardi, G., de Capoa, P., Di Staso, A., Estevez, A., Martin-Martin, M., Martin-Rojas, L., Perrone, V., Tent-Manclus, J.E., 2003. Oligocene-to-Early Miocene depositional and structural evolution of the Calabria-Peloritani Arc southern terrane (Italy) and geodynamic correlations with the Spain Betics and Morocco Rif. Geodinamica Acta 16 (2-6), 149-169.

Bossière, G., Peucat, J.J., 1985. New geochronological information by $\mathrm{Rb}-\mathrm{Sr}$ and U-Pb Investigations from the pre-Alpine basement of Grande Kabylie (Algeria). Canadian Journal of Earth Sciences 22 (5), 675-685.

Bossière, G., Peucat, J.J., 1986. Structural evidence and Rb-Sr, Ar-39-40 mica ages relationships for the existence of an Hercynian deep crustal shear zone in Grande Kabylie (Algeria) and its Alpine reworking. Tectonophysics 121 (2-4), 277-294.

Bouillin, J.P., Glacon, G., 1973. De-couverte de Cretace et d'Eocene de type Tellien charries sur le socle de la Petite Kabilye aux environes d'El Milia (Constantinois, Algerie). Compte Rendus de l'Académie des Sciences 267, 1517-1519.

Bouillin, J.P., Durand-Delga, M., Olivier, P., 1986. Betic-Rifian and Tyrrhenian arcs; distinctive features, genesis and development stages. Elsevier, Amsterdam, Netherlands, pp. 281-304.

Boukhalfa, K., Ismail-Lattrache, K.B., Riahi, S., Soussi, M., Khomsi, S., 2009. Analyse biostratigraphique et sédimentologique des séries éo-oligocènes et miocènes de la Tunisie septentrionale: implications stratigraphiques et géodynamiques. Comptes Rendus Geosciences 341 (1), 49-62.

Boyer, S.E., Elliott, D., 1982. Thrust systems. American Association of Petroleum Geologists Bulletin 66 (9), 1196-1230.

Bracene, R., de Lamotte, D.F., 2002. The origin of intraplate deformation in the Atlas system of western and central Algeria: from Jurassic rifting to CenozoicQuaternary inversion. Tectonophysics 357 (1-4), 207-226.

Broquet, P., Duée, G., Caire, A., Truillet, R., 1963. Distinction de deux series a facies flysch dans le Nord-Est silicien. Compte Rendus de l'Académie des Sciences de Paris 257 (19), 2856-2858.

Burgoyne, P.M., van Wyk, A.E., Anderson, J.M., Schrire, B.D., 2005. Phanerozoic evolution of plants on the African plate. Journal of African Earth Sciences 43, 13-52. 
Burke, K., Wells, G.L., 1989. Trans-African drainage system of the Sahara - was it the Nile. Geology 17 (8), 743-747.

Burollet, P.F., 1991. Structures and tectonics of Tunisia. Tectonophysics 195 (2-4), 359-369.

Caby, R., 1996. A review of the in Ouzzal granulitic terrane (Tuareg shield, Algeria): its significance within the Pan-African Trans-Saharan belt. Journal of Metamorphic Geology 14 (6), 659-666.

Caby, R., 2003. Terrane assembly and geodynamic evolution of central-western Hoggar: a synthesis. Journal of African Earth Sciences 37 (3-4), 133-159.

Caby, R., Dostal, J., Dupuy, C., 1977. Upper Proterozoic volcanic graywackes from northwestern Hoggar (Algeria) - geology and geochemistry. Precambrian Research 5 (3), 283-297.

Cainelli, C., 1994. Shelf processes and canyon/channel evolution controlling turbidite systems: examples from the Sergipe-Alagoas basin, Brazil. GCSSEPM Foundation 15th Annual Research Conference, Submarine Fans and Turbidite systems, December 4-7, 1994.

Caire, A., Duée, G., 1971. The Quartz pisolites from the Numidian originate in Sardinia, not in the Sahara. Compte Rendus Hebdomadaires des Seances de l'Academie des Sciences, Paris 270 (26), 1381-3183.

Carbone, S., Lentini, F., Sonnino, M., De Rosa, R., 1987. Il flysch numidico di Valsinni (Appennino lucano). Bollettino Della Societa Geologica Italiana 106 (2), 331-345.

Carminati, E., Wortel, M.J.R., Spakman, W., Sabadini, R., 1998. The role of slab detachment processes in the opening of the western-central Mediterranean basins: some geological and geophysical evidence. Earth and Planetary Science Letters 160 (3-4), 651-665.

Carmisciano, R., Coccioni, R., Corradini, D., D'alessandro, A., Guerrera, F., Loiacono, F., Moretti, E., Puglisi, D., Sabato, L., 1987. Nuovi datti sulle "successioni miste" inframioceniche dell'Algeria (Grande kabilia) e della Sicilia (Monti Nebrodi); Confronti con analoghe successioni torbiditiche nell'Arco di Gibilterra e nell'Appennino Lucano. Memorie della Societa Geologica Italiana 38, 551-576.

Carr, M.D., Miller, E.L., 1979. Overthrust emplacement of the Numidian Flysch Complex in the westernmost Mogod Mountains, Tunisia - summary. Geological Society of America Bulletin 90 (6), 513-515.

Carvajal, C.R., Steel, R.J., 2006. Thick turbidite successions from supply-dominated shelves during sea-level highstand. Geology 34 (8), 665-668.

Cassola, P., Giammarino, S., Puglisi, D., Villa, G., 1991. Nuovi dati sedimentologicopetrografici e biostratigrafici sulla formazione di Piedimonte (Sicilia nordorientale). Memorie della Societa Geologica Italiana 47, 213-223.

Cassola, P., Loiacono, F., Moretti, E., Nigro, F., Puglisi, D., Sbarra, R., 1995. The Reitano Flysch in the northern sector of Nebrodi Mountains (NE Sicily): sedimentological, petrographical and structural characters. Giornale di Geologia serie 3 (57), 195-217.

Catalano, R., Distefano, P., Vitale, F.P., 1995. Structural trends and paleogeography of the central and western Sicily Belt - new insights. Terra Nova 7 (2), 189-199.

Catalano, R., Di Stefano, P., Sulli, A., Vitale, F.P., 1996. Paleogeography and structure of the Central Mediterranean: Sicily and its offshore area. Tectonophysics 260 (4), 291-323.

Catuneanu, O., 2002. Sequence stratigraphy of clastic systems: concepts, merits, and pitfalls. Journal of African Earth Sciences 35 (1), 1-43.

Cello, G., Mazzoli, S., 1998. Apennine tectonics in southern Italy: a review. Journal of Geodynamics 27 (2), 191-211.

Chalouan, A., El Mrihi, A., El Kadiri, K., Bahmad, A., Salhi, F., Hlila, R., 2006. Mauretanian flysch nappe in the northwestern Rif Cordillera (Morocco): deformation chronology and evidence for a complex nappe emplacement. Tectonics of the Western Mediterranean and North Africa 262, 161-175.

Channell, J.E.T., Oldow, J.S., Catalano, R., D'Argenio, B., 1990. Paleomagnetically determined rotations in the western Sicillian fold and thrust belt. Tectonics 9 (4), 641-660.

Cheilletz, A., Ruffet, G., Marignac, C., Kolli, O., Gasquet, D., Feraud, G., Bouillin, J.P., 1999. Ar-40/Ar-39 dating of shear zones in the Variscan basement of Greater Kabylia (Algeria). Evidence of an Eo-Alpine event at $128 \mathrm{Ma}$ (Hauterivian-Barremian boundary): geodynamic consequences. Tectonophysics 306 (1), 97-116.

Chiocchini, U., Cipriani, N., 1996. Petrologic binary diagrams for characterizing and comparing arenites. Sedimentary Geology 103 (3-4), 281-289.

Cibin, U., Di Giulio, A., Martelli, L., Catanzariti, R., Poccianti, S., Rosselli, C., Sani, F., 2004 Factors controlling foredeep turbidite deposition: the case of Northern Apennines (Oligocene-Miocene, Italy). In: Lomas, S.A., Joseph, P. (Eds.), Confined Turbidite Systems. Geological Society Special Publication, pp. 115-134.

Clark, M.S., 1995. The Cozy Dell Formation; delta progradation and turbidite deposition during sea-level highstand. American Association of Petroleum Geologists Bulletin 79 (4), 581.

Cohen, C.R., 1980. Plate tectonic model for the Oligo-Miocene evolution of the western Mediterranean. Tectonophysics 68 (3-4), 283-311.

Coutelle, A., 1979. Structure des unites externes du Tell algerien de la region d'Akbou; succession des phases tectoniques. Compte Rendu Sommaire des Seances de la Societe Geologique de France 21 (1, Supplement), 20-22.

Covault, J.A., Normark, W.R., Romans, B.W., Graham, S.A., 2007. Highstand fans in the California borderland: the overlooked deep-water depositional systems. Geology 35 (9), 783-786.

Crespo-Blanc, A., de Lamotte, D.F., 2006. Structural evolution of the external zones derived from the Flysch trough and the South Iberian and Maghrebian paleomargins around the Gibraltar arc: a comparative study. Bulletin De La Societe Geologique De France 177 (5), 267-282.

Critelli, S., Mongelli, G., Perri, F., Martin-Algarra, A., Martin-Martin, M., Perrone, V., Dominici, R., Sonnino, M., Zaghloul, M.N., 2008. Compositional and geochemical signatures for the sedimentary evolution of the Middle Triassic-Lower Jurassic continental redbeds from western-central Mediterranean alpine chains. Journal of Geology 116 (4), 375-386.

de Capoa, P., Guerrera, F., Perrone, V., Serrano, F., Tramontana, M., 2000. The onset of the syn-orogenic sedimentation in the Flysch Basin of the Sicilian Maghrebids: state of the art and new biostratigraphic constraints. Eclogae Geologicae Helvetiae 93 (1) 65-79.

de Capoa, P., Di Staso, A., Guerrera, F., Perrone, V., Tramontana, M., Zaghloul, M.N., 2002. The Lower Miocene volcaniclastic sedimentation in the Sicilian sector of the Maghrebian Flysch Basin: geodynamic implications. Geodinamica Acta 15 (2), 141-157.

de Capoa, P., Di Staso, A., Guerrera, F., Perrone, V., Tramontana, M., 2004. The age of the oceanic accretionary wedge and onset of continental collision in the Sicilian Maghrebian Chain. Geodinamica Acta 17 (5), 331-348.

de Capoa, P., Di Staso, A., Perrone, V., Zaghloul, M.N., 2007. The age of the foredeep sedimentation in the Betic-Rifian Mauretanian units: a major constraint for the reconstruction of the tectonic evolution of the Gibraltar Arc. Comptes Rendus Geoscience 339 (2), 161-170.

De Galdeano, C.S., El Kadiri, K., Simancas, J.F., Hlila, R., Lopez-Garrido, A.C., El Mrihi, A Chalouan, A., 2006. Paleogeographical reconstruction of the Malaguide-Ghomaride Complex (Internal Betic-Rifian Zone) based on Carboniferous granitoid pebble provenance. Geologica Carpathica 57 (5), 327-336.

DeCelles, P.G., Giles, K.A., 1996. Foreland basin systems. Basin Research 8 (2), 105-123.

Dejong, K.A., 1975. Gravity tectonics or plate tectonics - example of Numidian Flysch, Tunisia. Geological Magazine 112 (4), 373-381.

Deptuck, M.E., Sylvester, Z., Pirmez, C., O'Byrne, C., 2007. Migration-aggradation history and 3-D seismic geomorphology of submarine channels in the Pleistocene Benin-major Canyon, western Niger Delta slope. Marine and Petroleum Geology 24, 406-433.

Dercourt, J., Gaetani, M., Vrielynck, B., Barrier, E., Biju-Duval, B., Brunet, M.F., Cadet, J.P., Crasquin, S., Sandulescu, M., 2000. Atlas Peri-Tethys, Palaeogeographical Maps. CCGM/CGMW, Paris: 24 Maps and Explanatory Notes. 269 pp.

Dickinson, W.R., Suczek, C.A., 1979. Plate-tectonics and sandstone compositions. AAPC Bulletin 63 (12), 2164-2182.

Didon, J., Hoyez, B., 1978. Le Numidien dans l'arc bético-rifian; hypothèses sur sa mise en place sédimentaire et tectonique. Annales de la Société Géologique du Nord, Ille 98, 9-24.

Didon, J., Durand-Delga, M., Komprobst, J., 1973. Homologies geologiques entre les deux rives du détroit de Gibraltar. Bulletin - Societe Geologique de France 15, 78-105.

Didon, J., Duranddelga, M., Esteras, M., Feinberg, H., Magnè, J., Suter, G., 1984. The Numidian Sandstones Formation in the Gibraltar Arch Stratigraphically Lies between Oligocene Clays and Burdigalian (Lower Miocene) Marls. Comptes Rendus De L Academie Des Sciences Serie 2299 (3), 121-128.

D'Lemos, R.S., Inglis, J.D., Samson, S.D., 2006. A newly discovered orogenic event in Morocco: Neoproterozic ages for supposed Eburnean basement of the Bou Azzer inlier, Anti-Atlas Mountains. Precambrian Research 147 (1-2), 65-78.

Dongarra, G., Ferla, P., 1982. Le argille di Portella Colla e del Flysch Numidico auct. (M. Madonie; Sicilia); Aspetti deposizionali e diagenetici. Rendiconti della Societa Italiana di Mineralogia e Petrologia 38 (3), 1119-1133.

Douady, C.J., Catzeflis, F., Raman, J., Springer, M.S., Stanhope, M.J., 2003. The Sahara as a vicariant agent, and the role of Miocene climatic events, in the diversification of the mammalian order Macroscelidea (elephant shrews). Proceedings of the National Academy of Sciences of the United States of America 100 (14), 8325-8330.

El Euchi, H., Fourati, L.F.H., Saidi, M., 1998. Structural style and hydrocarbon habitat in northern Tunisia. The Sixth Tunisian Petroleum Exploration and Production Conference (Tunis). Field Trip Guide Book(13).

El Euchi, H., Saidi, M., Fourati, L., El Maherssi, C., 2004. Northern Tunisia Thrust Belt: Deformation Models and Hydrocarbon Systems. AAPG Hedberg series, Deformation, Fluid Flow, and Reservoir Appraisal in Foreland Fold and Thrust Belts(1), pp. 371-390.

El Ghali, A., Ben Ayed, N., Bobier, C., Zargouni, F., Krima, A., 2003. Les manifestations tectoniques synsedimentaires associees a la compression eocene en Tunisie; implications paleogeographiques et structurales sur la marge Nord-Africaine. Comptes Rendus - Academie des sciences. Geoscience 335 (9), 763-771.

El Harfi, A., Lang, J., Salomon, J., Chellai, E.H., 2001. Cenozoic sedimentary dynamics of the Ouarzazate foreland basin (Central High Atlas Mountains, Morocco). International Journal of Earth Sciences 90 (2), 393-411.

El Kadiri, K., Chalouan, A., Bahmad, A., Salhi, F., Liemlahi, H., 2006a. “Transgressive washing" concept: a sequence stratigraphic approach for calci- and siliciclastic turbidites. In: Moratti, G., Chalouan, A. (Eds.), Tectonics of the Western Mediterranean and North Africa. Geological Society, London, Special Publications, pp. 45-53.

El Kadiri, K., Hlila, R., De Galdeano, C.S., Lopez-Garrido, A.C., Chalouan, A. Serrano, F. Bahmad, A., Guerra-Merchan, A., Liemlahi, H., 2006b. Regional correlations across the Internides-Externides front (northwestern Rif Belt, Morocco) during the Late Cretaceous-Early Burdigalian times: palaeogeographical and palaeotectonic implications. Tectonics of the Western Mediterranean and North Africa 262, 193-215.

Elter, P., Grasso, M., Parotto, M., Vezzani, L., 2003. Structural setting of the ApennineMaghrebian thrust belt. Episodes 26 (3), 205-211.

Ernst, S.R., Guasti, E., Dupuis, C., Speijer, R.P., 2006. Environmental perturbation in the southern Tethys across the Paleocene/Eocene boundary (Dababiya, Egypt): foraminiferal and clay mineral records. Marine Micropaleontology 60 (1), 89-111.

Eschard, R., Albouy, E., Deschamps, R., Euzen, T., Ayub, A., 2003. Downstream evolution of turbiditic channel complexes in the Pab Range outcrops (Maastrichtian, Pakistan). Marine and Petroleum Geology 20 (6-8), 691-710.

Estrada, F., Ercilla, G., Alonso, B., 2005. Quantitative study of a Magdalena submarine channel (Caribbean Sea): implications for sedimentary dynamics. Marine and Petroleum Geology 22 (5), 623-635. 
Faugères, J.C., Broquet, P., Duée, G., Imbert, P., 1992. Sedimentary Record of Volcanic and Paleocurrent Events in the Numidian Sandstones of Sicily - the Tuffites and Contourites of Karsa. Comptes Rendus De L Academie Des Sciences Serie 2315 (4), 479-486.

Faugères, J.C., Gonthier, E., Griboulard, R., Masse, L., 1993. Quaternary sandy deposits and canyons on the Venezuelan margin and south Barbados accretionary prism. Marine Geology 110 (1-2), 115-142.

Ferla, P., Alaimo, R., 1976. I graniti e le rocce porfiriche calc-alcaline e k-andesitiche ne conglomerato trasgressivo del Miocene inferiore dei monti Peloritani (Sicilia). Memorie della Societa Geologica Italiana 17, 123-133.

Ferrandini, M., Ferrandini, J., Loye-Pilot, M.D., Butterlin, J., Cravatte, J., Janin, M.C., 1998 Le Miocene du bassin de Saint-Florent (Corse); modalites de la transgression du Burdigalien superieur et mise en evidence du Serravallien. Geobios 31 (1), 125-137.

Ferry, J.N., Mulder, T., Parize, O., Raillard, S., 2005. Concept of equilibrium profile in deep-water turbidite system: effects of local physiographic changes on the nature of sedimentary process and the geometries of deposits. Geological Society, London, Special Publications 244 (1), 181-193.

Festa, V., Caggianelli, A., Kruhl, J.H., Liotta, D., Prosser, G., Gueguen, E., Paglionico, A., 2006. Late-Hercynian shearing during crystallization of granitoid magmas (Sila massif, southern Italy): regional implications. Geodinamica Acta 19 (3-4) 185-195.

Fiannacca, P., Williams, I.S., Cirrincione, R., Pezzino, A., 2008. Crustal contributions to Late Hercynian peraluminous magmatism in the southern Calabria-Peloritan Orogen, southern Italy: petrogenetic inferences and the gondwana connection. Journal of Petrology 49 (8), 1497-1514.

Fildes, C., Stow, D., Riahi, S., Soussi, M., Patel, U., Milton, A.J., Marsh, S., 2010. European provenance of the Numidian Flysch in northern Tunisia. Terra Nova 22 (2), 94-102.

Fluteau, F., Ramstein, G., Besse, J., 1999. Simulating the evolution of the Asian and African monsoons during the past $30 \mathrm{Myr}$ using an atmospheric general circulation model. Journal of Geophysical Research 104 (D10), 11995-12018.

Folk, R.L., 1951. Stages of textural maturity in sedimentary rocks. Journal of Sedimentary Research 21, 127-130.

Fornelli, A., 1998. Petrological features of a Numidian section in the Lucanian Apennine (southern Italy). Geological Journal 33 (3), 177-191.

Fornelli, A., Piccarreta, G., 1997. Mineral and chemical provenance indicators in some early Miocene sandstones of the Southern Apennines (Italy). European Journal of Mineralogy 9 (2), 433-447.

Fraser, A.J., Hilkewich, D., Syms, R., Penge, J., Raposo, A., Simon, G., 2005. Angola Block 18; a deep-water exploration success story. In: Dore, A.G. Vining, B.A. (Eds.) Petroleum Geology: North-West Europe and Global Perspectives - Proceedings of the 6th Petroleum Geology Conference. Geological Society, London, pp. 1199-1216.

Frizon de Lamotte, D., 2005. About the Cenozoic inversion of the Atlas domain in North Africa. Comptes Rendus Geosciences 337 (5), 475-476.

Gaetani, M., Dercourt, J., Vrielynck, B., 2003. The Peri-Tethys Programme: achievements and results. Episodes 26 (2), 79-93.

Garzanti, E., Doglioni, C., Vezzoli, G., Ando, S., 2007. Orogenic belts and orogenic sediment provenance. Journal of Geology 115 (3), 315-334.

Gaudette, H.E., Hurley, P.M., Lajmi, T., 1975. Source area of the Numidian flych of Tunisia as suggested by detrital zircon ages. The Geological Society of America Annua Meetings, 7, September 1975, Boulder Colorado, pp. 1083-1084.

Gaudette, H.E., Hurle, P.M., Lajmi, T., 1979. Provenance studies in Tunisia by U-Pb ages of detrital zircons. American Association of Petroleum Geologists Bulletin 63, 456.

Gee, M.J.R., Gawthorpe, R.L., Bakke, K., Friedmann, S.J., 2007. Seismic geomorphology and evolution of submarine channels from the Angolan continental margin. Journal of Sedimentary Research 77 (5-6), 433-446.

Geel, T., Roep, T.B., 1998. Oligocene to middle Miocene basin development in the Eastern Betic Cordilleras, SE Spain (Velez Rubio Corridor-Espuna): reflections of West Mediterranean plate-tectonic reorganizations. Basin Research 10 (3), 325-343.

Gelard, J.P., 1969. Le flysch a base schisto-greseuse de la bordure meridionale et orientale du massif de Chellata (Grande-Kabylie, Algerie). Compte Rendu Sommaire des Seances de la Societe Geologique de France 8, 292-293.

Géry, B. 1983. Age and tectonic situation of the allochthonous sedimentary formations in Northern Grande Kabylie - an example in the Djebel Aissa-Mimoun. Comptes Rendus De L Academie Des Sciences Serie 2297 (9), 729-734

Ghienne, J., Deynoux, M., 1998. Large-scale channel fill structures in Late Ordovician glacial deposits in Mauritania, Western Sahara. Sedimentary Geology 119 (1-2) 149-151.

Ghienne, J.F., Boumendjel, K., Paris, F., Videt, B., Racheboeuf, P., Salem, H.A., 2007. The Cambrian-Ordovician succession in the Ougarta Range (western Algeria, North Africa) and interference of the Late Ordovician glaciation on the development of the Lower Palaeozoic transgression on northern Gondwana. Bulletin of Geosciences 82 (3), 183-214.

Giacomini, F., Bomparola, R.M., Ghezzo, C., Guldbransen, H., 2006. The geodynamic evolution of the Southern European Variscides: constraints from the $\mathrm{U} / \mathrm{Pb}$ geochronology and geochemistry of the lower Palaeozoic magmatic-sedimentary sequences of Sardinia (Italy). Contributions to Mineralogy and Petrology 152 (1), $19-42$

Gigliuto, L.G., Ouazani-Touhami, A., Puglisi, D., Puglisi, G., Zaghloul, M.N., 2004 Petrography and geochemistry of granitoid pebbles from the Oligocene-Miocene deposits of the internal Rifian chain (Morocco): a possible new hypothesis of provenance and paleogeographical implications. Geologica Carpathica 55 (3), 261-272.

Giunta, G., 1985. Problematiche ed ipotesi sul bacino numidico nelle Maghrebidi siciliane. Bollettino della Societa Geologica Italiana 104 (2), 239-256.
Golonka, J., 2004. Plate tectonic evolution of the southern margin of Eurasia in the Mesozoic and Cenozoic. Tectonophysics 381 (1-4), 235-273.

Gomez, F., Beauchamp, W., Barazangi, M., 2000. Role of the Atlas Mountains (northwest Africa) within the African-Eurasian plate-boundary zone. Geology 28 (9), 775-778.

Gomez-pugnaire, M.T., Fernandezsoler, J.M., 1987. High-pressure metamorphism in metabasites from the Betic Cordilleras (SE Spain) and its evolution during the Alpine orogeny. Contributions to Mineralogy and Petrology 95 (2), 231-244.

Gottis, C., 1953. Stratigraphie et tectonique du " flysch " numidien en Tunisie septentrionale. Compte Rendus Hebdomadaires des Seances de l'Academie des Sciences, Paris 236, 1059-1061.

Goudie, A.S., 2005. The drainage of Africa since the cretaceous. Geomorphology 67 (3-4), 437-456.

Grasso, M., Pedley, H.M., Maniscalco, R., 1994. The application of a late Burdigalian-early Langhian highstand event in correlating complex Tertiary orogenic carbonate successions within the central Mediterranean. Géologie Méditerranéenne 21 (1-2), 69-83.

Guerrera, F., Martinalgarra, A., Perrone, V., 1993. Late Oligocene-Miocene Syn-/-LateOrogenic Successions in Western and Central Mediterranean Chains from the Betic Cordillera to the Southern Apennines. Terra Nova 5 (6), 525-544.

Guerrera, F., Martin-Martin, M., Perrone, V., Tramontana, M., 2005. Tectono-sedimentary evolution of the southern branch of the Western Tethys (Maghrebian Flysch Basin and Lucanian Ocean): consequences for Western Mediterranean geodynamics. Terra Nova 17 (4), 358-367.

Guiraud, R., Bosworth, W., Thierry, J., Delplanque, A., 2005. Phanerozoic geological evolution of Northern and Central Africa: an overview. Journal of African Earth Sciences 43 (1-3), 83-143.

Hammor, D., Bosch, D., Caby, R., Bruguier, O., 2006. A two-stage exhumation of the Variscan crust: U-Pb LA-ICP-MS and Rb-Sr ages from Greater Kabylia, Maghrebides. Terra Nova 18 (5), 299-307.

Haq, B.U., Hardenbol, J., Vail, P.R., 1987. Chronology of fluctuating sea levels since the Triassic. Science 235 (4793), 1156-1167.

Haughton, P.D.W., 2000. Evolving turbidite systems on a deforming basin floor, Tabernas, SE Spain. Sedimentology 47 (3), 497-518.

Heinio, P., Davies, R.J., 2007. Knickpoint migration in submarine channels in response to fold growth, western Niger Delta. Marine and Petroleum Geology 24, 434-449.

Hlila, R., El Kadiri, K., Chalouan, A., El Mrihi, A., 2004. Late Eocene-Burdigalian transgressive cover of the Betico-Rifan internal zones; paleogeographic and paleotectonic significance. Congres Geologique International, Resumes 32 (1), 769-770.

Hoyez, B., 1975. Dispersion du materiel quartzeux dans les formations aquitaniennes de Tunisie septentrionale et d' Algerie nord-orientale. Bulletin - Societe Geologique de France 25 (6), 1147-1156.

Huyghe, P., Foata, M., Deville, E. Mascle, G., Caramba Working, G. 2004. Channel profiles through the active thrust front of the southern Barbados prism. Geology 32 (5), 429-432.

Iannace, A., Vitale, S., D'Errico, M., Mazzoli, S., Di Staso, A., Macaione, E., Messina, A., Reddy, S.M. Somma, R. Zamparelli, V Zattin, M. Bonardi, G, 2007. The carbonate tectonic units of northern Calabria (Italy): a record of Apulian palaeomargin evolution and Miocene convergence, continental crust subduction, and exhumation of HP-LT rocks. Journal of the Geological Society 164, 1165-1186.

Inglis, J.D., MacLean, J.S., Samson, S.D., D'Lemos, R.S., Admou, H., Hefferan, K., 2004. A precise U-Pb zircon age for the Bleid granodiorite, Anti-Atlas, Morocco: implications for the timing of deformation and terrane assembly in the eastern Anti-Atlas. Journal of African Earth Sciences 39, 277-283.

Ivaldi, J.P., 1977. Natural and artificial thermoluminescence of Kabyle Permo-Trias and Saharian Continental Inter-Calaire Detrital Series (Algeria) - data for a paleogeography of Numidian sandstones. Comptes Rendus Hebdomadaires Des Seances De L Academie Des Sciences Serie D 284 (8), 611-614.

Jeddi, R.S., 1994. Les depots silico-clastiques oligo-miocenes en Tunisie atlasique centrale; modele d'environnement et evolution paleogeographique. ETAP Memoir Series 7, 419-440.

Jerram, D.A., Mountney, N., Holzforster, F., Stollhofen, H., 1999. Internal stratigraphic relationships in the Etendeka group in the Huab Basin, NW Namibia: understanding the onset of flood volcanism. Journal of Geodynamics 28 (4-5), 393-418.

Johansson, M., Braakenburg, N.E., Stow, D.A.V., Faugères, J.C., 1998. Deep-water massive sands: facies, processes and channel geometry in the Numidian Flysch, Sicily. Sedimentary Geology 115 (1-4), 233-265.

John, C.M., Mutti, M., Adatte, T., 2003. Mixed carbonate-siliciclastic record on the North African margin (Malta) - coupling of weathering processes and mid Miocene climate. GSA Bulletin 115 (2), 217-229.

Kheidri, H.L., Zazoun, R.S., Sabaou, N., 2007. Neogene tectonic history of the Sub-Bibanic and M'sila Basins, northern Algeria: implications for hydrocarbon potential. Journal of Petroleum Geology 30 (2), 159-173.

Khomsi, S., Bedir, M., Soussi, M., Ben Jemia, M.G., Ben Ismail-Lattrache, K., 2006. Highlight of Middle-Late eocene compressional events in the subsurface of eastern Tunisia (Sahel): generality of the Atlasic phase in North Africa. Comptes Rendus Geoscience 338 (1-2), 41-49.

Kilian, C.M., 1931. Des principaux complexes continentaux du Sahara. Compte Rendu Sommaire des Seances de la Societe Geologique de France 9, 109-111.

Knott, S.D., 1987. The Liguride Complex of Southern Italy - a Cretaceous to Paleogene Accretionary Wedge. Tectonophysics 142 (2-4), 217-226.

Kohn, B.P., Eyal, M., Feinstein, S., 1992. A major late Devonian-early Carboniferous (Hercynian) thermotectonic event at the NW margin of the Arabian-Nubian sheild: evidence from Zircon fission track dating. Tectonics 11 (5), 1018-1027.

Kuster, D., Liegeois, J.P., Matukov, D., Sergeev, S., Lucassen, F., 2008. Zircon geochronology and $\mathrm{Sr}, \mathrm{Nd}, \mathrm{Pb}$ isotope geochemistry of granitoids from Bayuda 
Desert and Sabaloka (Sudan): evidence for a Bayudian event (920-900 Ma) preceding the Pan-African orogenic cycle (860-590 Ma) at the eastern boundary of the Saharan Metacraton. Precambrian Research 164 (1-2), 16-39.

Lahondére, J.C., Feinberg, H., Haq, B.U., 1979. Dating of Numidian sandstone of Eastern Algeria - structural consequences. Comptes Rendus Hebdomadaires Des Seances De L Academie Des Sciences Serie D 289 (4), 383-386.

Lancelot, J., Reille, J.L., Broquet, P., Mattauer, M., 1976. Datation U - Pb des zircons detritiques du flysch numidien d'Espagne et de Sicile; consequences paleogeographiques ( $\mathrm{U}-\mathrm{Pb}$ dating of detrital zircons in the Numidian flysch of Spain and Sicily; paleogeographic consequences.). Reunion Annuelle des Sciences de la Terre (4), Societe Geologique de France.

Lancelot, J., Reille, J.L., Wezel, F.C., 1977. Etude morphologique et radiochronologique de zircons détritiques des flyschs "numidien" et "gréso-micacé". Bulletin De La Societe Geologique De France 7 (19), 773-780.

Lancelot, J.R., Allegret, A., Ponce, Iglesias, de Leon, M., 1985. Outline of Upper Precambrian and Lower Paleozoic evolution of the Iberian Peninsula according to U-Pb dating of zircons. Earth and Planetary Science Letters 74 (4), 325-337.

Laval, F., 1974. Precisions sur la tectonique des flyschs dans l'Est de la Grande Kabylie (Algerie). Comptes Rendus Hebdomadaires des Seances de l'Academie des Sciences, Serie D: Sciences Naturelles 279 (20), 1609-1612.

Laval, F., 1992. Gravity depositional systems and sedimentary megasequence of the Numidian Flysch Formation, North and East of the Grande Kabylie Massif (Algeria). Geodinamica Acta 5 (4), 217-233.

Lavier, L.L., Steckler, M.S., Brigaud, F., 2001. Climatic and tectonic control on the Cenozoic evolution of the West African margin. Marine Geology 178 (1-4), 63-80.

Leblanc, D., Feinberg, H., 1982. Tectonic and stratigraphic improvements about the Numidian of Eastern Rif (Morocco) - geodynamic implications. Bulletin De La Societe Geologique De France 24 (4), 861-865.

Lefranc, J.P., Guiraud, R., 1990. The continental intercalaire of northwestern Sahara and its equivalents in the neighbouring regions. Journal of African Earth Sciences 10 (1-2), 27-77.

Lentini, F., Carbone, S., Di Stefano, A., Guarnieri, P., 2002. Stratigraphical and structural constraints in the Lucanian Apennines (southern Italy): tools for reconstructing the geological evolution. Journal of Geodynamics 34 (1), 141-158.

Llinás Agrasar, E., 2004. Crocodile remains from the Burdigalian (lower Miocene) of Gebel Zelten (Libya). Geodiversitas 26 (2), 309-321.

Loiacono, F., Paglionica, A., Pellegrino, M.C., 1983. Le quarzoareniti del Flysch Numidico di Campomaggiore (PZ); indagini per l'utilizzazione in campo industriale. Geologia Applicata e Idrogeologia 18 (1), 63-80.

Lonergan, L., White, N., 1997. Origin of the Betic-Rif mountain belt. Tectonics 16 (3), 504-522.

Lujan, M., Crespo-Blanc, A., Balanya, J.C., 2006. The Flysch Trough thrust imbricate (Betic Cordillera): a key element of the Gibraltar Arc orogenic wedge. Tectonics 25 (6), 1-17.

Maate, A., Martin-Perez, J.A., Martin-Algarra, A., Serrano, F., Aguado, R., Martin-Martin, M., El Hajjaji, K., 1995. Le Burdigalien inferieur de Boujarrah (Rif septentrional, Maroc) et la signification paleotectonique des series miocenes transgressives sur les zones internes betico-rifaines. Comptes Rendus de l'Academie des Sciences, Serie II. Sciences de la Terre et des Planetes 320 (1), 15-22.

Maffione, M., Speranza, F., Faccenna, C., Cascella, A., Vignaroli, G., Sagnotti, L., 2008. A synchronous Alpine and Corsica-Sardinia rotation. Journal of Geophysical Research-Solid Earth 113 (B3), 25.

Magné, J., Raymond, D., 1972. North of Great Kabylia (Algeria), Numidian with Age between Middle Oligocene and Lower Burdigalian. Comptes Rendus Hebdomadaires Des Seances De L Academie Des Sciences Serie D 274 (23), 3052-3055.

Markwick, P.J., 1998. Fossil crocodilians as indicators of Late Cretaceous and Cenozoic climates; implications for using palaeontological data in reconstructing palaeoclimate. Palaeogeography, Palaeoclimatology, Palaeoecology 137 (3-4), 205-271.

Masrouhi, A., Ghanmi, M., Slama, M.M.B., Youssef, M.B., Vila, J.M., Zargouni, F., 2008. New tectono-sedimentary evidence constraining the timing of the positive tectonic inversion and the Eocene Atlasic phase in northern Tunisia: implication for the North African paleo-margin evolution. Comptes Rendus Geoscience 340 (11) 771-778.

Mauffret, A., de Lamotte, D.F., Lallemant, S., Gorini, C., Maillard, A., 2004. E-W opening of the Algerian Basin (Western Mediterranean). Terra Nova 16 (5), 257-264.

Mazzoleni, P., 1991. Le rocce profiriche nel conglomerato basale della formazione di Stilo-Capo d'Orlando. Memorie della Societa Geologica Italiana 47, 557-565.

Meulenkamp, J.E., Sissingh, W., 2003. Tertiary palaeogeography and tectonostratigraphic evolution of the Northern and Southern Peri-Tethys platforms and the intermediate domains of the African-Eurasian convergent plate boundary zone. Palaeogeography Palaeoclimatology Palaeoecology 196 (1-2), 209-228.

Micheletti, F., Fornelli, A., Piccarreta, G., Barbey, P., Tlepolo, M., 2008. The basement of Calabria (Southern Italy) within the context of the Southern European Variscides: LA-ICPMS and SIMS U-Pb zircon study. Lithos 104 (1-4), 1-11.

Miller, K.G., Wright, J.D., Fairbanks, R.G., 1991. Unlocking the ice house - OligoceneMiocene oxygen isotopes, eustasy, and margin erosion. Journal of Geophysical Research-Solid Earth and Planets 96 (B4), 6829-6848.

Milner, S.C., Le Roex, A.P., O'Connor, J.M., 1995. Age of Mesozoic igneous rocks in northwestern Namibia, and their relationship to continental breakup. Journal of Geological Society of London 152, 97-104.

Mitchum, J.R.M., Van Wagoner, J.C., 1991. High-frequency sequences and their stacking patterns: sequence-stratigraphic evidence of high-frequency eustatic cycles. Sedimentary Geology 70 (2-4), 131-147.

Monaco, C., De Guidi, G., 2006. Structural evidence for Neogene rotations in the eastern Sicilian fold and thrust belt. Journal of Structural Geology 28 (4), 561-574.

Montanari, L., 1986. Aspetti tettono-sedimentari dell' Oligocene e Miocene in Sicilia e aree contigue. Giornale di Geologia, serie 3 48, 99-112.
Moreau, J., Ghienne, J.F., Le Heron, D.P., Rubino, J.L., Deynoux, M., 2005. 440 Ma ice stream in North Africa. Geology 33 (9), 753-756.

Moretti, E., Coccioni, R., Guerrera, F., Lahondére, J.C., Loiacono, F., Puglisi, D., 1988. Numidian Flysch of the Constantine Mountains (Tell-Orientale, Algeria). American Association of Petroleum Geologists Bulletin 72 (8), 1015.

Moretti, E., Coccioni, R., Guerrera, F., Lahondére, J.C., Loiacono, F., Puglisi, D., 1991. The Numidian Sequence between Guelma and Constantine (Eastern Tell, Algeria). Terra Nova 3 (2), 153-165.

Morley, C.K., 1988. The tectonic evolution of the Zoumi Sandstone, western Moroccan Rif. Journal of Geological Society 145, 55-63.

Mutti, E., Tinterri, R., Benevelli, G., di Biase, D., Cavanna, G., 2003. Deltaic, mixed and turbidite sedimentation of ancient foreland basins. Marine and Petroleum Geology 20 (6-8), 733-755.

Mutti, E., Bernoulli, D., Lucchi, F.R., Tinterri, R., 2009. Turbidites and turbidity currents from Alpine 'flysch' to the exploration of continental margins. Sedimentology 56 (1), 267-318.

Neubauer, F., 2002. Evolution of late Neoproterozoic to early Paleozoic tectonic elements in Central and Southeast European Alpine mountain belts: review and synthesis. Tectonophysics 352 (1-2), 87-103.

Oldow, J.S., Channell, J.E.T., Catalano, R., D'Argenio, B., 1990. Contemporaneous thrusting and large-scale rotations in the western Sicilian fold and thrust belt Tectonics 9 (4), 661-681.

Paquette, J.L., Caby, R., Djouadi, M.T., Bouchez, J.L., 1997. U-Pb dating of the end of the Pan-African orogeny in the Tuareg shield: the post-collisional syn-shear Tioueine pluton (Western Hoggar, Algeria), Symposium 55 on Post-Collisional Magmatism. Strasbourg, France, pp. 245-253.

Parize, O., Beaudoin, B., 1987. Clastic dikes in the Numidian Flysch (Tunisia, Sicily) their relations with the paleomorphology. Comptes Rendus De L Academie Des Sciences Serie 2304 (3), 129-134.

Parize, O., Beaudoin, B., Burollet, P.F., Cojan, I., Fries, G., Pinault, M., 1986. A northern origin for the sandy material of Numidian Flysch (Sicily and Tunisia). Comptes Rendus De L Academie Des Sciences Serie 2303 (18), 1671-1674.

Parize, O., Beaudoin, B., Fries, G., 1999. Deep-water massive sands: facies, processes and channel geometry in the Numidian Flysch, Sicily - comment. Sedimentary Geology 127 (1-2), 111-118.

Patterson, R.T., Blenkinsop, J., Cavazza, W., 1995. Planktic foraminiferal biostratigraphy and $87 \mathrm{Sr} / 86 \mathrm{Sr}$ isotopic stratigraphy of the Oligocene-to-Pleistocene sedimentary sequence in the southeastern Calabrian microplate, Southern Italy. Journal of paleontology 69 (1), 7-20.

Pattison, S.A.J., 2005. Isolated highstand shelf sandstone body of turbiditic origin, lower Kenilworth Member, Cretaceous Western Interior, Book Cliffs, Utah, USA Sedimentary Geology 177 (1-2), 131-144.

Paull, C.K., Mitts, P., Ussler, W., Keaten, R., Greene, H.G., 2005. Trail of sand in uppe Monterey Canyon: offshore California. Geological Society of America Bulletin 117 (9-10), 1134-1145.

Peakall, J., McCaffrey, B., Kneller, B., 2000. A process model for the evolution, morphology, and architecture of sinuous submarine channels. Journal of Sedimentary Research 70 (3), 434-448.

Pedley, H.M., Renda, P., 1998. A regionally correlatable high to lowstand signal from late Burdigalian-early Langhian outliers in western Sicily, Italy. Bollettino Della Societa Geologica Italiana 117 (1), 39-53.

Pescatore, T., Renda, P., Tramutoli, M., 1992. “Tufiti di Tusa” e flysch Numidico nella Lucania centrale (Appennino meridionale). Reudiconto della Academia delle Scieza F 59 (131), 57-72.

Peucat, J.J., Mahdjoub, Y., Drareni, A., 1996. U-Pb and Rb-Sr geochronological evidence for late Hercynian tectonic and Alpine overthrusting in Kabylian metamorphic basement massifs (northeastern Algeria). Tectonophysics 258 (1-4), 195-213.

Peucat, J.J., Drareni, A., Latouche, L., Deloule, E., Vidal, P., 2003. U-Pb zircon (TIMS and SIMS) and Sm-Nd whole-rock geochronology of the Gour Oumelalen granulitic basement, Hoggar massif, Tuareg shield, Algeria. Journal of African Earth Sciences 37 (3-4), 229-239.

Peucat, J.J., Capdevila, R., Drareni, A., Mahdjoub, Y., Kahoui, M., 2005. The Eglab massif in the West African Craton (Algeria), an original segment of the Eburnean orogenic belt: petrology, geochemistry and geochronology. Precambrian Research 136 (3-4), 309-352.

Piqué, A., Tricart, P., Guiraud, R., Laville, E., Bouaziz, S., Amrhar, M., Ouali, R.A., 2002. The Mesozoic-Cenozoic Atlas belt (North Africa): an overview. Geodinamica Acta 15, 185-208.

Posamentier, H.W., 2001. Lowstand alluvial bypass systems: incised vs. unincised American Association of Petroleum Geologists Bulletin 85 (10), 1771-1793.

Puglisi, D., 1987. Le successioni torbiditiche cretacico-terziarie della Sicilia nordorientale nel quadro dell'evoluzione del settore meridionale dell'Arco CalabroPeloritano e della Catena Maghrebide siciliana. Giornale di Geologia (serie $3^{\circ}$ ) 49 (1), 167-185.

Puglisi, D., 1994. Caratteri petrochimici delle arenarie delle unita torbiditiche oligomioceniche della Sicilia nord-orientale. Mineralogica et Petrographica Acta 37, 393-415.

Puglisi, D., 2008. Oligocene-Miocene sandstone suites from the Gibraltar and CalabriaPeloritani Arcs: provenance changes and paleogeographic implications. Geologica Carpathica 59 (6), 525-535.

Puglisi, D., Zaghloul, M.N., Maate, A., 2001. Evidence of sedimentary supply from plutonic sources in the Oligocene-Miocene flyschs of the Rifian Chain (Morocco); provenance and paleogeographic implications. Bollettino Della Societa Geologica Italiana 120 (1), 55-68.

Putignano, M.L., Schiattarella, M., 2008. Geology, geomorphology, and exhumation modalities of the Monte Motola structure, Cilento region, southern Italy. Bollettino Della Societa Geologica Italiana 127 (3), 477-493. 
Raymond, D., 1976. Sedimentary and tectonic evolution of northwest Great Kabylia Algeria during the course of the Alpine Cycle. Annales Scientifiques de l'Universite de Besancon Geologie 26, 47-76.

Riahi, S., Khalfa, K.B., Soussi, M., Ismail-Lattrache, K.B., 2007. The Numidian Flysch Complex of Onshore Tunisia (Southern Kroumirie Range) - facies analysis and stratigraphic review. EAGE Conference Letters, 3rd North African/Mediterranean Petroleum \& Geosciences Conference and Exhibition. Tripoli, Libya, 26 - 28 February 2007.

Ross, L.M., Houseknecht, D.W., 1987. Petrographic constraints on provenance and sediment dispersal patterns, Atokan Sandstones of Arkoma Basin, Oklahoma and Arkansas. Association of Petroleum Geologists Bulletin 71 (8), 996.

Rossi, C., Kalin, O., Arribas, J., Tortosa, A., 2002. Diagenesis, provenance and reservoir quality of Triassic TAGI sandstones from Ourhoud field, Berkine (Ghadames) Basin, Algeria. Marine and Petroleum Geology 19 (2), 117-142.

Rossi, P., Cocherie, A., Fanning, C.M., Deloule, T., 2006. Variscan to eo-Alpine events recorded in European lower-crust zircons sampled from the French Massif Centra and Corsica, France. Lithos 87, 235-260.

Ruddiman, W.F., Sarnthein, M., Backman, J., Baldauf, J.G., Curry, W.B., Dupont, L.M., Janecek, T.R., Pokras, E.M., Raymo, M.E., Stabell, B., Stein, R., Tiedemann, R., et al., 1989. Late Miocene to Pleistocene evolution of climate in Africa and the lowlatitude Atlantic; overview of Leg 108 results. Proceedings of the Ocean Drilling Program, Scientific Results 108, 463-484.

Saddiqi, O., El Haimer, F.Z., Michard, A., Barbarand, J., Ruiz, G.M.H., Mansour, E.M. Leturmy, P., Frizon de Lamotte, D., 2009. Apatite fission-track analyses on basement granites from south-western Meseta, Morocco: paleogeographic implications and interpretation of AFT age discrepancies. Tectonophysics 475 (1), 29-37.

Samuel, A., Kneller, B., Raslan, S., Sharp, A., Parsons, C., 2003. Prolific deep-marine slope channels of the Nile Delta, Egypt. Association of Petroleum Geologists Bulletin 87 (4), 541-560.

Sanz de Galdeano, C., Serrano, F., Lopez Garrido, A.C., Martin Perez, J.A., 1993. Palaeogeography of the late Aquitanian-early Burdigalian basin in the western Betic internal zone. Geobios 26 (1), 43-55.

Schaltegger, U., 1993. The evolution of the polymetamorphic basement in the Central Alps unraveled by precise $\mathrm{U}-\mathrm{Pb}$ zircon dating. Contributions to Mineralogy and Petrology 113 (4), 466-478.

Selley, R.C., 1968. Near-shore marine and continental sediments of the Sirte basin, Libya. Quaterly Journal of the Geological Society of London 124, 419-460.

Serrano, F., Sanz de Galdeano, C., El Kadiri, K., Guerra-Merchan, A., Lopez-Garrido, A.C. Martin-Martin, M., Hlila, R., 2006. Oligocene-early Miocene transgressive cover of the Betic-Rif internal zone; revision of its geologic significance. Eclogae Geologicae Helvetiae 99 (2), 237-253.

Shanmugam, G., 2008. The constructive functions of tropical cyclones and tsunamis on deep-water sand deposition during sea level highstand: implications for petroleum exploration. Association of Petroleum Geologists Bulletin 92 (4), 443-471.

Shultz, M.R., Hubbard, S., 2003. 2003. Slump-generated topographic control of deepwater sediment dispersal and preservation patterns and resultant stratigraphic architecture, Tres Pasos Formation, southern Chile. In: Chidsey Thomas Jr. C. (Ed.), 2003 AAPG Annual Convention with SEPM. American Association of Petroleum Geologists and Society of Economic Paleontologists and Mineralogists, Tulsa, OK, United States.

Shultz, M.R. Fildani, A., Cope, T.D., Graham, S.A., 2005. 2005. Deposition an stratigraphic architecture of an outcropping ancient slope system; Tres Pasos Formation, Magallanes Basin, southern Chile. In: Hodgson David, M., Flint Stephen, S. (Eds.), Submarine Slope Systems; Processes and Products. Geological Society of London. London, United Kingdom.

Sinclair, H.D., 1997. Tectonostratigraphic model for underfilled peripheral foreland basins an Alpine perspective. Geological Society of America Bulletin 109 (3), 324-346.

Sluijs, A., Brinkhuis, H., Crouch, E.M., John, C.M., Handley, L., Munsterman, D., Bohaty, S.M., Zachos, J.C., Reichart, G.J., Schouten, S., Pancost, R.D., Damste, J.S.S., Welters, N.L.D. Lotter, A.F., Dickens, G.R., 2008. Eustatic variations during the Paleocene-Eocene greenhouse world. Paleoceanography 23 (4), 1-18.

Speranza, F., Maniscalco, R., Grasso, M., 2003. Pattern of orogenic rotations in centraleastern Sicily: implications for the timing of spreading in the Tyrrhenian Sea. Journal of the Geological Society 160, 183-195.

Stow, D.A.V., Mayall, M., 2000. Deep-water sedimentary systems: new models for the 21st century. Marine and Petroleum Geology 17 (2), 125-135.

Stow, D.A.V., Johansson, M., Braakenburg, N., Faugères, J.C., 1999. Deep-water massive sands: facies, processes and channel geometry in the Numidian Flysch, Sicily reply. Sedimentary Geology 127 (1-2), 119-123.

Stromberg, S.G., Bluck, B., 1998. Turbidite facies, fluid-escape structures and mechanisms of emplacement of the Oligo-Miocene Aljibe Flysch, Gibraltar Arc, Betics, southern Spain. Sedimentary Geology 115 (1-4), 267-288.

Suayah, I.B., Miller, J.S., Miller, B.V., Bayer, T.M., Rogers, J.J.W., 2006. Tectonic significance of Late Neoproterozoic granites from the Tibesti massif in southern Libya inferred from $\mathrm{Sr}$ and $\mathrm{Nd}$ isotopes and $\mathrm{U}-\mathrm{Pb}$ zircon data. Journal of African Earth Sciences 44 (4-5), 561-570.

Sutherland, P.K., 1988. Late Mississippian and Pennsylvanian depositional history in the Arkoma Basin Area, Oklahoma and Arkansas. Geological Society of America Bulletin 100 (11), 1787-1802.

Tahiri, A. Simancas, J.F, Azor, A, Galindo-Zaldivar, J., Gonzalez Lodeiro, F. El Hadi, H., Martinez Poyatos, D., Ruiz-Constan, A., 2007. Emplacement of ellipsoid-shaped (diapiric?) granite; structural and gravimetric analysis of the Oulmes Granite (Variscan Meseta, Morocco). Journal of African Earth Sciences 48 (5), 301-313.

Talbi, F., Melki, F., Ben Ismail-Lattrache, K., Alouani, R., Tlig, S., 2008. Le Numidien de la Tunisie septentrionale: donnees stratigraphiques et interpretation geodynamique. Estudios Geologicos 64 (1), 31-44.

Torricelli, S., Biffi, U., 2001. Palynostratigraphy of the Numidian Flysch of northern Tunisia (Oligocene-early Miocene). Palynology 25, 29-55.

Tricart, P., Torelli, L., Argnani, A., Rekhiss, F., Zitellini, N., 1994. Extensional collapse related to compressional uplift in the Alpine Chain off Northern Tunisia (Central Mediterranean). Tectonophysics 238 (1-4), 317-329.

Trombetta, A., Cirrincione, R., Corfu, F., Mazzoleni, P., Pezzino, A., 2004. Mid-Ordovician $\mathrm{U}-\mathrm{Pb}$ ages of porphyroids in the Peloritan Mountains (NE Sicily): palaeogeographical implications for the evolution of the Alboran microplate. Journal of the Geological Society 161, 265-276.

Uroza, C.A., Steel, R.J., 2008. A highstand shelf-margin delta system from the Eocene of West Spitsbergen, Norway. Sedimentary Geology 203 (3-4), 229-245.

Van Sickel, W.A., Kominz, M.A., Miller, K.G., Browning, J.V., 2004. Late Cretaceous and Cenozoic sea-level estimates: backstripping analysis of borehole data, onshore New Jersey. Basin Research 16 (4), 451-465.

Vanhouten, F.B., 1980. Mid-Cenozoic fortuna formation, Northeastern Tunisia - record of late Alpine activity on North African cratonic margin. American Journal of Science 280 (10), 1051-1062.

Vila, J.M., 1978. Definition de la nappe neritique constantinoise, element structural majeur de la chaine alpine d'Algerie orientale. Bulletin de la Societe Geologique de France 20 (5), 791-794.

Vila, J.M., Feinberg, H., Lahondère, J.C., Gourinard, Y., Chouabbi, A., Magné, J., DurandDelga, M., 1995. The sandy uppermost Oligocene channel and the Miocene of SidiAffif area in their East Algerian structural setting - the Saharan Origin of the Numidian and the calendar of the Miocene overthrusts. Comptes Rendus De L Academie Des Sciences Serie 2320 (10), 1001-1009.

Walsh, G.J., Aleinikoff, J.N., Benziane, F., Yazidi, A., Armstrong, T.R., 2002. U-Pb zircon geochronology of the Paleoproterozoic Tagragra de Tata inlier and its Neoproterozoic cover, western Anti-Atlas, Morocco. Precambrian Research 117 (1-2), 1-20.

Weber, M.E., Wiedicke, M.H., Kudrass, H.R., Huebscher, C., Erlenkeuser, H., 1997. Active growth of the Bengal Fan during sea-level rise and highstand. Geology (Boulder) 25 (4), 315-318.

Weber, M.E., Wiedicke-Hombach, M., Kudrass, H.R., Erlenkeuser, H., 2003. Bengal Fan sediment transport activity and response to climate forcing inferred from sediment physical properties. Sedimentary Geology 155 (3-4), 361-381.

Weijermars, R., 1991. Geology and Tectonics of the Betic Zone, Se Spain. Earth-Science Reviews 31 (3-4), 153-236.

Wezel, F.C., 1969. Lineamenti Sedimentologico Del Flysch Numidico Della Sicilia NordOrientale. Memorie Degli Instituti Di Geologia e Mineralogia Del L'Universita Di Padova 26, 1-32.

Wezel, F.C., 1970a. Numidian Flysch - an Oligocene - Early Miocene continental rise deposit off African platform. Nature 228 (5268), 275-276.

Wezel, F.C., 1970b. Geologica Del Flysch Numidico Della Sicilia Nord-Orientale. Memorie-Societa Geological Italiana 9 (2), 225-280.

Wildi, W., 1983. The orogenic belt of the Rif (Morocco) and the Tell (Algeria, Tunisia) structure, stratigraphy, paleogeographic and tectonic evolution from the Triassic to the Miocene. Revue De Geologie Dynamique Et De Geographie Physique 24 (3), 201-297.

Woolfe, K.J., Larcombe, P., Naish, T., Purdon, R.G., 1998. Lowstand rivers need not incise the shelf: an example from the Great Barrier Reef, Australia, with implications for sequence stratigraphic models. Geology 26 (1), 75-78.

Wynn, R.B., Cronin, B.T., Peakall, J., 2007. Sinuous deep-water channels: genesis, geometry and architecture. Marine and Petroleum Geology 24, 341-387.

Yaich, C., 1992a. Dynamics of the Oligomiocene detritic facies of Tunisia. Journal of African Earth Sciences 15 (1), 35-47.

Yaich, C., 1992b. Sedimentologie, tectonique (et variations relatives du niveau marin) dans les formations du Miocene inferieur a moyen, Tunisie centrale et orientale. Géologie Méditerranéenne 19 (4), 249-264.

Yaich, C., Hooyberghs, H.J.F., Durlet, C., Renard, M., 2000. Stratigraphic correlation between the Numidian formation (North Tunisia) and Oligo-Miocene deposits of central Tunisia. Comptes Rendus De L Academie Des Sciences Serie 2 Fascicule aSciences De La Terre Et Des Planetes 331 (7), 499-506.

Zachos, J.C., Shackleton, N.J., Revenaugh, J.S., Palike, H., Flower, B.P., 2001. Climate response to orbital forcing across the Oligocene-Miocene boundary. Science 292 (5515), 274-278.

Zaghloul, M.N., Guerrera, F., Loiacono, F., Maiorano, P., Puglisi, D., 2002. Stratigraphy and petrography of the Beni Ider Flysch in the Tetouan area (Rif chain, Morocco). Bollettino Della Societa Geologica Italiana 121 (1), 69-85.

Zaghloul, M.N., Di Staso, A., De Capoa, P., Perrone, V., 2007. Occurrence of upper Burdigalian silexite beds within the Beni Ider Flysch Fm. in the Ksar-es-Seghir area (Maghrebian Flysch Basin, Northern Rif, Morocco): stratigraphic correlations and geodynamic implications. Bollettino Della Societa Geologica Italiana 126 (2), 223-239. 